\title{
Culpa in het Belgisch strafrecht: een poging tot synthese
}

Filip Van Volsem

\section{Inleiding}

\section{I.I. Culpa: afbakening van het onderwerp}

I. Het begrip culpa is voor de Belgische strafrechtspracticus geen courant taalgebruik. De term komt vanzelfsprekend voor in de klassieke handboeken over het Belgisch strafrecht en in tijdschriftartikelen over het moreel misdrijfbestanddeel, maar wordt in de strafrechtspraak nagenoeg niet gebruikt. Een opzoeking in de juridische databank Jura met de gecombineerde trefwoorden strafrecht-culpa levert slechts een beperkt aantal relevante hits op en een opzoeking in de rechtspraakdatabank Juridat met het trefwoord culpa leidt tot slechts één arrest van de strafkamer van het Hof van Cassatie.

2. Culpa doet denken aan schuld. Schuld is in het Belgisch strafrecht echter geen eenduidig begrip, maar wordt in meerdere betekenissen gebruikt. ${ }^{22}$ Schuld wordt gebruikt in de betekenis van:

- feitelijke toerekening, en wijst aldus op de causale relatie tussen het feit en de dader;

- het moreel bestanddeel van het misdrijf, en kan dan bestaan in opzet of onachtzaamheid;

- onachtzaamheid als mogelijke schuldvorm: de dader heeft niet ingezien wat hij gemakkelijk had kunnen en behoren te doen;

- verwijtbaarheid, en heeft dan betrekking op het al dan niet bestaan van schulduitsluitingsgronden (dwaling en dwang);

- de vaststelling van het daderschap, en wordt dan niet zozeer in zijn materiële maar wel in zijn processuele betekenis ${ }^{93}$ gebruikt;

- schuldonbekwaamheid, waarmee dan toerekeningsvatbaarheid wordt bedoeld.

A. De Nauw, Inleiding tot het Algemeen Strafrecht, Brugge: Die Keure 20Io, p. 44, nr. 79.c (hierna: De Nauw, Inleiding Algemeen Strafrecht 2010); L. Dupont en R. Verstraeten, Handboek Belgisch Strafrecht, Leuven: Acco I990, p. 239, nr. 398 (hierna: Dupont-Verstraeten); C. Van den Wyngaert, m.m.v. S. Vandromme, Strafrecht \& Strafprocesrecht in hoofdlijnen, I, Antwerpen: Maklu 20II, p. 286 (hierna Van den Wyngaert, Strafrecht \& Strafprocesrecht 2011).

93 Zie art. 323 Wetboek van Strafvordering m.b.t. de aan de jury te stellen schuldvraag. 
3. In dit preadvies wordt met culpa of schuld in zijn enge betekenis onachtzaamheid of fout bedoeld als een van schuldvormen van het moreel bestanddeel van het misdrijf. In deze bijdrage wordt:

- de onachtzaamheid gekaderd binnen de structuur van het misdrijf;

- vervolgens gefocust op de invulling van het begrip onachtzaamheid specifiek met betrekking tot de misdrijven van opzettelijke doding en onopzettelijke slagen of verwondingen;

- in hoofdlijnen de kritiek overlopen die de rechtsleer uit op de wijze waarop de Belgische rechtspraak het foutbegrip opvat;

- verder een overzicht gegeven van de voorstellen die er zijn geweest om aan het foutbegrip van de artikelen 4I8-420 Sw. te sleutelen;

- kort de Franse wetswijziging van 2000 aangeraakt;

- ten slotte getracht uit dit alles een conclusie te trekken.

\section{I.2. De situering van de onachtzaamheid binnen de structuur van het misdrijf}

4. Een misdrijf bestaat uit bestanddelen die de delictsinhoud bepalen. Elk misdrijf vereist twee bestanddelen: het materieel bestanddeel (de uiterlijke verschijningsvorm) en het moreel bestanddeel (de schuldvorm waarmee de gedraging wordt gesteld). Deze bestanddelen behoren tot de objectieve structuur van het misdrijf, wat wil zeggen dat ze door de wet worden bepaald. ${ }^{94}$

5. De enkele omstandigheid dat een gedraging overeenstemt met de wettelijk bepaalde delictsinhoud impliceert niet automatisch dat de dader kan worden gestraft. ${ }^{95}$ De potentiële strafbaarheid kan verdwijnen door de aanwezigheid van gronden die de wederrechtelijkheid, de verwijtbaarheid, de toerekeningsvatbaarheid of de strafwaardigheid wegnemen.

6. De aanwezigheid van het materieel en het moreel bestanddeel volstaat niet voor strafbaarheid. Het gedrag moet bovendien onrechtmatig of wederrechtelijk zijn, ${ }^{96}$ wat in het Belgisch strafrecht zo wordt begrepen dat er geen door de wet of het recht bepaalde omstandigheden aanwezig zijn die de strafbaarheid neutraliseren. ${ }^{77}$ Het gaat om de rechtvaardigingsgronden wettige verdediging, gebod van de overheid en noodtoestand.

De Nauw, Inleiding Algemeen Strafrecht 2010, p. 37, nr. 7I.

De Nauw, Inleiding Algemeen Strafrecht 2010, p. 38 , nr. 72.

96 Zie over het onderscheid tussen de materiële en de formele wederrechtelijkheidsleer en de vraag of de wederrechtelijkheid werkelijk een afzonderlijk misdrijfbestanddeel is: DupontVerstraeten, p. 207-2I2, nr. 334-342; A. De Nauw, 'Is de materiële wederrechtelijkheid een nuttig begrip in het Belgisch strafrecht?', Panopticon 1992, p. 135-156; L. Dupont, 'De situering van het begrip wederrechtelijkheid in de theorie van het misdrijf', in: Liber Amicorum Jules D'Haenens, Gent: Mys \& Breesch I993, p. I27-I45.

97 De Nauw, Inleiding Algemeen Strafrecht 2010, p. 38, nr. 72; Van den Wyngaert, Strafrecht \& Strafprocesrecht 2011, p. I78-I79 en 182. 
7. Er kunnen omstandigheden zijn waardoor, ook al is de gedraging van de dader wederrechtelijk, die gedraging hem in concreto niet kan worden verweten. ${ }^{98}$ Het gaat om de dwang en de onoverwinnelijke dwaling. Die schulduitsluitingsgronden houden verband met de verwijtbaarheid.

8. Het moreel bestanddeel en de schulduitsluitingsgronden staan dicht bij elkaar. Ze werden omschreven als twee kanten van dezelfde munt: het moreel bestanddeel als een positieve invulling van het schuldbegrip en de schulduitsluitingsgronden als de negatieve. Dwaling en dwang zouden zowel opzet als onachtzaamheid uitsluiten of anders geformuleerd opzet en onachtzaamheid stemmen overeen met het niet voorhanden zijn van dwaling en dwang. ${ }^{99}$

9. Daaruit kan nochtans niet worden afgeleid dat beide begrippen elkaar overlappen. Niet elke dwang (er is de vereiste van de afwezigheid van een voorafgaande fout) of elke dwaling (ze moet onoverwinnelijk zijn) leidt tot schulduitsluiting en dus tot niet-verwijtbaarheid zodat de positieve en de negatieve component van de schuldbegrip niet volledig overlappen. ${ }^{100}$ Bovendien wordt voorgehouden dat het moreel bestanddeel van het misdrijf losstaat van de verwijtbaarheid ${ }^{\text {ror }}$ en dat overmacht bij opzettelijke misdrijven het opzet niet doet verdwijnen, maar aan de handeling of aan het verzuim het karakter van schuldige gedraging of aan het verzuim het karakter van schuldige gedraging ontneemt. Een dader die handelt ingevolge overmacht kan opzettelijk handelen, hoewel de gedraging hem onder bepaalde voorwaarden niet kan worden verweten. Niettegenstaande het opzet, treft de dader geen verwijt, omdat hij moreel gedwongen was. ${ }^{\text {I02 }}$

Io. Geestesgestoorden, die een als misdaad of wanbedrijf omschreven feit hebben gepleegd (art. 7 Wet Bescherming Maatschappij, art. 8, § I, Wet 2I april 2007), en jeugdige delinquenten, die een als misdrijf omschreven feit hebben gepleegd (art. 36, $4^{\circ}$, Jeugdbeschermingswet), zijn in beginsel niet toerekeningsvatbaar. Het moreel bestanddeel mag niet worden verward met de toerekeningsvatbaarheid, waarvan de gronden soms subjectieve gronden van rechtvaardiging worden genoemd. Geestesgestoorde en jeugdige delinquenten zijn nochtans niet gerechtvaardigd. Zij hebben objectief gezien het misdrijf in al zijn bestanddelen gepleegd. ${ }^{103}$

II. In een aantal gevallen zal de dader - ook al heeft hij wederrechtelijk gehandeld, zijn de feiten hem verwijtbaar en is hij toerekeningsvatbaar - aan bestraffing

98 De Nauw, Inleiding Algemeen Strafrecht 2010, p. 38, nr. 72.

99 Van den Wyngaert, Strafrecht \& Strafprocesrecht 2011, p. I82, 287 en 3 Io.

Ioo Van den Wyngaert, Strafrecht \& Strafprocesrecht 2011, p. 287 en 310.

IoI De Nauw, Inleiding Algemeen Strafrecht 2010, p. 38 , nr. 72.

I02 De Nauw, Inleiding Algemeen Strafrecht 2010, p. 38, nr. 72.

I03 De Nauw, Inleiding Algemeen Strafrecht 2010, p. 38-39, nr. 72. Zie over de discussie die daaromtrent in de rechtsleer bestaat: A. De Nauw, 'De niet-toerekeningsvatbaarheid sluit niet noodzakelijkerwijze het opzet uit', in: F. Deruyck, M. De Swaef, J. Rozie, M. Rozie, P. Traest en R. Verstraeten (red.), De wet voorbij. Liber Amicorum Luc Huybrechts, Antwerpen: Intersentia 2010, p. 65-76. 
ontsnappen, omdat de wetgever strafuitsluitende verschoningsgronden heeft bepaald. Op die manier wordt de strafwaardigheid van de dader weggenomen. ${ }^{104}$

I2. Het onderscheid tussen enerzijds de bestanddelen van het misdrijf en anderzijds de gronden van rechtvaardiging (wederrechtelijkheid), schulduitsluiting (verwijtbaarheid), niet-toerekeningsvatbaarheid en strafwaardigheid (strafuitsluitende verschoningsgronden) is processueel relevant. Het Openbaar Ministerie moet in beginsel het bewijs leveren van het bestaan van alle bestanddelen van het misdrijf. Indien een beklaagde een van de vermelde gronden aanvoert, moet het Openbaar Ministerie alleen maar de onjuistheid ervan bewijzen, indien de aanvoering enige grond van geloofwaardigheid bevat. ${ }^{105}$

\section{I.3. Het moreel bestanddeel van het misdrijf: algemeen}

I3. Elk misdrijf vereist naast een materieel ook een moreel bestanddeel. ${ }^{106}$ Misdrijven die enkel bestaan uit een materieel element en die om die reden (zuiver) materiële misdrijven worden genoemd, zijn strijdig met het beginsel nullum crimen sine culpa. Het Belgisch strafrecht is een schuldstrafrecht en een objectieve aansprakelijkheid wordt principieel afgewezen. ${ }^{107}$

I4. Volgens de cassatierechtspraak ${ }^{108}$ geldt ook voor misdrijven waarvan in de wettelijke omschrijving geen sprake is van opzet of onachtzaamheid, dat ze niet strafbaar zijn alleen maar door het plegen van het materiële feit. Uit de afwezigheid in de misdrijfomschrijving van een moreel bestanddeel volgt niet dat een dergelijk bestanddeel niet is vereist. ${ }^{109}$ Het stellen van een verboden handeling of het verzuimen van een geboden handeling moet altijd de uitdrukking zijn van een vrije en bewuste handeling. ${ }^{\text {Io }}$ Ook het EHRM lijkt vertrekkend van de artikelen 6.2 en 7 EVRM de leer van de zuiver materiële misdrijven te verwerpen. ${ }^{\text {II }}$

I04 De Nauw, Inleiding Algemeen Strafrecht 2010, p. 39, nr. 72; Dupont-Verstraeten, p. I65-I66, nr. 248.

I05 De Nauw, Inleiding Algemeen Strafrecht 2010, p. 39, nr. 73.

Io6 N. Colette-Basecqz en N. Blaise, Manuel de droit pénal général, Louvain-la-Neuve 2010, p. 258-260 (hierna: Colette-Basecqz en Blaise, Manuel de droit pénal général); B. Spriet, 'Elk misdrijf - ook dat uit het bijzonder strafrecht - vereist een moreel of schuldbestanddeel', (noot onder Cass. I3 december 1994), RW I995-96, 534, nr. 3; A. Weyemberg en L. Kennes, Droit pénal spécial, Limal: Anthemis, 20II, p. 6, nr. Io (hierna: Weyemberg en Kennes, Droit pénal spécial).

I07 F. Kuty, Principes généraux du droit pénal belge, II, L’infraction pénale, Brussel: Larcier 20Io, p. 2I3-2I5, nr. 1085-I086 (hierna Kuty, Principes généraux du droit pénal belge, II); Van den Wyngaert, Strafrecht \& Strafprocesrecht 2011, p. I8I en 292-293.

Io8 Cass. I2 mei I987, AC I987-88, II94, concl. J. Du Jardin; Cass. I3 december I994, RW I995-96, 533, noot B. Spriet.

I09 Cass. I9 november I997, P.97.I077.F, AC I997, II80, JLMB I999, 48, noot C. Pevée en C. Sevrain; Cass. 4 oktober 2006, P.06.0545.F, AC 2006, I913.

IIo J. Du Jardin, Concl. bij Cass. I2 mei i987, AC I987-88, II94.

III EHRM, Salabiaku t. Frankrijk, 7 oktober I988, S\$ 26-30; ERHM, Sud Fondi SRL e.a. t. Italië, 20 januari 2009, § II6. 
I5. Het Belgisch Strafwetboek omschrijft niet wat het moreel bestanddeel van het misdrijf is. ${ }^{12}$ De rechtspraak van het Hof van Cassatie mag op dit vlak niet eenduidig worden genoemd ${ }^{113}$ en in elk geval is er uit die rechtspraak noch uit die van de feitenrechters een algemene en omvattende leer omtrent dit misdrijfbestanddeel af te leiden. ${ }^{\mathrm{II}}{ }^{4}$ De rechtspraktijk laat de discussies daaromtrent liever over aan de academici. ${ }^{15}$ De rechtsleer heeft zich mede naar aanleiding van de voorstellen tot herziening van het Belgisch Strafwetboek vooral in de jaren zeventig en tachtig van de vorige eeuw met de theorie van het moreel bestanddeel ingelaten. ${ }^{\mathrm{II}}{ }^{\mathrm{C}}$ Die discussie lijkt net als de hervormingsplannen van het Belgische Strafwetboek zelf sindsdien grotendeels te zijn stilgevallen.

I6. In de rechtsleer zijn grosso modo twee richtingen te onderscheiden. ${ }^{117} \mathrm{Er}$ is vooreerst de klassieke richting, die teruggaat naar Haus ${ }^{\mathrm{I} 18}$ als een van de grondleggers van het Strafwetboek en die steunt op de parlementaire voorbereiding van dit wetboek. Die leer onderscheidt twee schuldvormen, namelijk opzet en onachtzaamheid. Ze neemt aan dat in beginsel alleen opzettelijke gedragingen strafrechtelijk worden gesanctioneerd, zodat de wetgever het opzet als schuldvorm niet uitdrukkelijk moet opnemen in de misdrijfomschrijving, tenzij hij een bijzonder opzet zou noodzakelijk achten. Aantastingen van strafrechtelijk beschermde waarden uit onachtzaamheid zijn in beginsel niet strafbaar, tenzij de wetgever dit uitdrukkelijk bepaalt. Onachtzaamheid vormt aldus de ondergrens van de strafrechtelijke schuld. ${ }^{\text {II }}$

17. De andere richting is gesteund op de door Legros in zijn thesis ${ }^{120}$ ontwikkelde theorie van 'la faute infractionnelle' welke is doorgesijpeld in het voorontwerp van Strafwetboek dat Legros in 1985 als Koninklijk commissaris voor de hervorming van het Strafwetboek heeft ingediend. Ze gaat uit van een tweedelige indeling van de misdrijven gebaseerd op het al dan niet uitdrukkelijk bepalen door de wetgever van een bijzonder moreel bestanddeel. Aldus maakt Legros een onderscheid tussen enerzijds misdrijven waarvoor de wetgever in een bijzonder moreel bestanddeel heeft voorzien en misdrijven waarvoor de wetgever in de delictomschrijving omtrent het moreel bestanddeel geen concrete omschrijving verstrekt. Voor de

II2 De Nauw, Inleiding tot het Algemeen Strafrecht 2010, p. 43, nr. 79; Vanhoudt-Calewaert II, p. 333, nr. 647.

II3 De Nauw, Inleiding tot het Algemeen Strafrecht 2010, p. 43, nr. 79.

II4 Weyemberg en Kennes, Droit pénal spécial, p. 9, nr. I8.

II5 O. Michiels, 'Quelques précisions sur les notions de faute, de dol éventuel et de dol praeter-intentionnel quand il y a mort d'homme', (noot onder Corr. Verviers 27 februari 2008), JT 2009, 493, nr. 7.

II6 Van den Wyngaert, Strafrecht \& Strafprocesrecht 2011, p. 304.

II7 De Nauw, Inleiding tot het Algemeen Strafrecht 2010, p. 43, nr. 79; Vanhoudt-Calewaert, II, p. 333, nr. 647.

II8 J. Haus, Principes généraux du droit pénal belge, I, Gent: Hoste I879, p. 209, nr. 295 (hierna Haus, Principes généraux du droit pénal belge, I).

II9 B. Spriet, 'Elk misdrijf - ook dat uit het bijzonder strafrecht - vereist een moreel of schuldbestanddeel', lc, 535, nr. 8; Dupont-Verstraeten, p. 249, nr. 4I8.

I20 R. Legros, Lélément moral dans les infractions, Luik: Desoer 1952, 352p. Zie ook R. Legros, Opzet, in APR, Gent: Story-Scientia 1959, 54p. 
eerste categorie kan het bijzonder moreel bestanddeel bestaan in bijzonder opzet of in onachtzaamheid. Voor de tweede categorie gaat Legros uit van schuld voor wetsinbreuk. Voor die misdrijven bestaat volgens hem het moreel bestanddeel in de loutere overtreding van de strafwet, maar kan de dader aan bestraffing ontsnappen door zich te beroepen op dwaling of dwang. Legros verwerpt het begrip algemeen opzet. Dit begrip heeft voor hem slechts een negatieve inhoud. Wetens is niets anders dan dat de dader niet dwaalde, willens houdt in dat de dader niet handelde onder dwang. Algemeen opzet is niets anders dan het ontbreken van een grond van schulduitsluiting. ${ }^{\text {.2I }}$

I8. F. Kuty ${ }^{122}$ heeft recent de leer van Legros herwerkt en zijn visie op het moreel misdrijfbestanddeel kan als volgt worden samengevat:

- de aard van het misdrijf (misdaad, wanbedrijf of overtreding dan wel misdrijf strafbaar gesteld door het Strafwetboek of een bijzondere strafwet) heeft geen relevantie voor het moreel bestanddeel;

- er moeten drie vormen van fout worden onderscheiden: de schuld door wetsinbreuk (la faute infractionnelle), de voorafgaande fout (la faute antérieure) en de opzettelijke fout (la faute intentionnelle);

- de schuld door wetsinbreuk geldt voor elk misdrijf, ook als de wetgever geen moreel bestanddeel heeft bepaald; ze bestaat in het bewust en vrij plegen van het misdrijf zonder dat de dader zijn handeling kan rechtvaardigen;

- de voorafgaande fout is het moreel bestanddeel voor de onachtzaamheidsmisdrijven; de dader heeft bewust en vrij gehandeld of verzuimd met niet-gewilde gevolgen; de wetgever moet uitdrukkelijk bepalen dat de voorafgaande fout, of anders gezegd onachtzaamheid, het moreel bestanddeel is;

- de opzettelijke fout bestaat in het opzettelijk en met kennis van zaken handelen of verzuimen en het realiseren van de eventuele gevolgen; dat is het opzet in de eerste graad; daarnaast onderscheidt hij nog een opzet in de tweede graad indien de wetgever een bijzonder oogmerk vereist; opzet is slechts vereist als de wetgever dit im- of expliciet heeft bepaald.

I9. Welk moreel bestanddeel moet de feitenrechter, die in meerderheid de klassieke leer is getrouw gebleven, in acht nemen? Indien de strafwetgever voor een bepaald misdrijf het moreel bestanddeel heeft bepaald (algemeen opzet, bijzonder opzet, onachtzaamheid of eventueel een mengvorm), is de zaak eenvoudig. Dit moreel bestanddeel is noodzakelijk, maar volstaat voor strafbaarheid. In veel gevallen - en dat is vooral zo in de bijzondere strafwetten ${ }^{123}$ - bewaart de strafwetgever evenwel

I2I De Nauw, Inleiding tot het Algemeen Strafrecht 2010, p. 48, nr. 88; Dupont-Verstraeten, p. 265, nr. 458; Van den Wyngaert, Strafrecht \& Strafprocesrecht 2011, p. 310; Vanhoudt-Calewaert, II, p. 343-346, nr. 667-677.

I22 Kuty, Principes généraux du droit pénal belge, II, p. 209 e.v., nr. Io8o e.v.

I23 B. Spriet, 'Elk misdrijf - ook dat uit het bijzonder strafrecht - vereist een moreel of schuldbestanddeel', lc, 534, nr. 5 . 
het stilzwijgen over het moreel bestanddeel. De klassieke leer neemt dan aan dat de volgende schuldvorm is vereist: ${ }^{124}$

- voor misdaden: opzet;

- voor wanbedrijven uit het Strafwetboek: opzet;

- voor wanbedrijven omschreven in bijzondere strafwetten die uitsluitend of hoofdzakelijk strafbepalingen bevatten: opzet;

- voor wanbedrijven omschreven in bijzondere wetgevingen waar de strafbepalingen bijkomend zijn aan de andere bepalingen: minstens onachtzaamheid;

- voor overtredingen: minstens onachtzaamheid.

Voor de twee laatste categorieën is het niet van belang of het moreel bestanddeel bestaat in opzet dan wel in onachtzaamheid, maar minstens moet de dader onachtzaam zijn geweest. Of hij onachtzaam was dan wel met opzet heeft gehandeld, is wel van belang voor eventuele deelneming. ${ }^{125}$

20. De vraag naar de noodzaak van het bestaan van een moreel bestanddeel van het misdrijf moet worden onderscheiden van het bewijs van dit bestanddeel. ${ }^{126}$ Uit het vermoeden van onschuld, dat een algemeen rechtsbeginsel is en dat uitdrukkelijk is opgenomen in artikel 6.2 EVRM en artikel I4.2. IVBPR, volgt dat de vervolgende partij in de regel het voorhanden zijn van de misdrijfbestanddelen moet bewijzen en dus ook het moreel bestanddeel. ${ }^{127}$ De klassieke leer nam reeds aan dat onvoldoende was dat opzet of onachtzaamheid werden vermoed, maar dat zij dienden te worden bewezen, zij het dat de rechter het bestaan ervan kon afleiden uit de feiten. ${ }^{228}$

2I. In dat verband kan worden gewezen op in de rechtsleer verdedigde stellingen dat voor die gedragingen die strafbaar zijn ongeacht of ze opzettelijk dan wel uit onachtzaamheid zijn gesteld (wanbedrijven uit de bijzondere strafwetten waar de strafbepalingen bijkomstig zijn, en de overtredingen, tenzij de regelgever het moreel bestanddeel uitdrukkelijk zou hebben bepaald) het moreel bestanddeel uit het plegen van de feiten volgt. Vandaar dat er wordt gesproken van misdrijven waar het moreel bestanddeel bestaat in schuld door wetsinbreuk, reglementaire misdrijven, materiële misdrijven of ook nog contraventionele wanbedrijven, zijnde wanbedrijven met het kenmerk van een overtreding. ${ }^{129}$

I24 Dupont-Verstraeten, p. 252, nr. 427 en p. 26, nr. 454; Haus, Principes généraux du droit pénal belge, I, p. 209-2Io, nr. 295-296); B. Spriet, 'Elk misdrijf-ook dat uit het bijzonder strafrecht-vereist een moreel of schuldbestanddeel', Ic, 535, nr. 7; Van den Wyngaert, Strafrecht \& Strafprocesrecht 2011, p. 305; Vanhoudt-Calewaert, II, p. 335, nr. 652. Zie voor een kritische benadering: J. Verhaegen, 'L'exigence de l'intention coupable dans les infractions aux lois et règlements', Rev. dr. pén. I986, 95I-953.

I25 B. Spriet, 'Elk misdrijf - ook dat uit het bijzonder strafrecht - vereist een moreel of schuldbestanddeel', lc, 535, nr. 8 .

I26 Cass. I2 mei I987, AC I987-88, II94, concl. J. Du Jardin; Colette-Basecqz en Blaise, Manuel de droit pénal général, 257; De Nauw, Inleiding tot het Algemeen Strafrecht 2010, p. 48, nr. 87.

I27 Van den Wyngaert, Strafrecht \& Strafprocesrecht 2011, p. 294.

I28 Haus, Principes généraux du droit pénal belge, I, p. 228, nr. en p. 234, nr. 323 in fine.

I29 N. Denies en N. Basceqz, 'Droit de l'environnement en droit économique et social: réflexions sur l'élément moral dans les lois et règlements particuliers', Rev. dr. pén. 1994, p. 473-508; Colette- 
22. Het Hof van Cassatie zit voor dat soort misdrijven op dezelfde lijn. Zo werd geoordeeld:

- dat het douane- en accijnsstrafrecht in de regel de enkele overtreding van de regelgeving bestraft zonder rekening te houden met de bedoeling van de dader, evenwel onverminderd overmacht of onoverwinnelijke rechtsdwaling; ${ }^{130}$

- indien een milieustrafbepaling stilzwijgend is over de schuldvorm, het moreel bestanddeel kan bestaan in onachtzaamheid en dit moreel bestanddeel kan worden afgeleid uit het louter materieel gepleegde feit en de vaststelling dat het feit aan de beklaagde kan worden toegerekend, met dien verstande evenwel dat de beklaagde vrijuit gaat wanneer een schulduitsluitingsgrond wordt aangetoond; $;^{13 \mathrm{I}}$

- in het verkeerstrafrecht dat wanneer de wet in de delictomschrijving geen moreel bestanddeel vermeldt, dit bestanddeel bestaat uit opzet of onachtzaamheid, tenzij de wetgever dit laatste zou hebben uitgesloten. Indien dit laatste niet het geval is, kan de rechter het moreel bestanddeel afleiden uit het materiële feit van de overtreding voor zover de overtreder geen schulduitsluitingsgrond aannemelijk maakt. ${ }^{132}$

23. Wel stelt het Hof dat de strafbaarheid wegens een misdrijf of de schuld aan een misdrijf de wetenschap vereist dat het misdrijf wordt gepleegd. ${ }^{133}$ Over de precieze draagwijdte van die overweging bestaat discussie, maar het lijkt niet zo te zijn dat onwetendheid uit onachtzaamheid of anders gesteld een niet-onverwinnelijke dwaling tot niet-strafbaarheid zou leiden. ${ }^{134}$

24. Door toe te laten dat het voorhanden zijn van het moreel bestanddeel wordt afgeleid uit het materieel plegen van de feiten, aanvaardt het Hof van Cassatie dat de bewijslast voor de vervolgende partij wordt vergemakkelijkt door het hanteren van een feitelijk vermoeden of anders gezegd een feitelijk element dat niet meer uitdrukkelijk moet worden bewezen, tenzij de aanwezigheid met een zekere graad van geloofwaardigheid wordt betwist. ${ }^{135}$ Uit de EHRM-rechtspraak ${ }^{136}$ volgt dat het gebruik van vermoedens niet is verboden, op voorwaarde dat een en ander gebeurt

Basecqz en Blaise, Manuel de droit pénal général, p. 268; De Nauw, Inleiding tot het Algemeen Strafrecht 2010, p. 47, nr. 87; J. D'Haenens, 'L'incrimination non intentionnelle dans le droit pénal codifié et réglementaire', Rev. dr. pén. I994, p. 462; Van den Wyngaert, Strafrecht \& Strafprocesrecht 2011, p. 306-307; Vanhoudt-Calewaert, II, p. 334, nr. 649.

I30 O.m. Cass. II februari I997, P.96.ı03..N, AC I997, 20I; Cass. I9 november I997, P.97.I077.F, AC I997, II80, JLMB I999, 48, noot C. Pevée en C. Sevrain.

I3I Cass. 8 april 2008, P.08.00o6.N, AC 2008, 866.

I32 Cass. 8 oktober 2002, P.oI.II49, AC 2002, 2087.

I33 Cass. Io oktober I989, AC I989-90, I89; Cass. I9 november I997, P.97.I077.F, AC I997, II80, JLMB I999, 48, noot C. Pevée en C. Sevrain; Cass. 4 oktober 2006, P.o6.0545.F, AC 2006, I9I3.

I34 B. Spriet, 'Elk misdrijf - ook dat uit het bijzonder strafrecht - vereist een moreel of schuldbestanddeel', lc, 536, nr. Ir. Zie nochtans: C. Pevée en C. Sevrain, 'Du nouveau dans la matière de l'élément moral', (noot onder Cass. ig november 1997), JLMB I999, 50-5I, nr. 2.

I35 B. Spriet, 'Elk misdrijf - ook dat uit het bijzonder strafrecht - vereist een moreel of schuldbestanddeel', lc, 536-537, nr. I2.

I36 EHRM, Salabiaku t. Frankrijk, 7 oktober I988, §§ 26-30; EHRM, Pham Hoang t. Frankrijk, 25 september I992, \$§ 32-36; EHRM, Janosevic t. Zweden, 23 juli 2002, \$§ 96-IIo. 
binnen redelijke grenzen, dat rekening wordt gehouden met de inzet van de zaak en dat dit de uitoefening van de in artikel 6.2 EVRM bedoelde rechten niet volledig uitholt, wat inhoudt dat dit vermoeden steeds weerlegbaar moet zijn. ${ }^{137}$ Dat is hier zeker het geval.

\section{I.4. Het moreel bestanddeel: het opzet}

25. Opzet (dolus) is de doelgerichte wil van de dader de gedraging te stellen die de wet gebiedt of de gedraging niet te stellen die de wet gebiedt. ${ }^{13^{8}}$ De dader heeft wetens en willens de wederrechtelijke gedraging gesteld, ongeacht de gevolgen, terwijl hij in staat was zich wetsconform te gedragen. ${ }^{\mathrm{I} 9}$ In het opzet worden verschillende graden of schakeringen onderscheiden (algemeen opzet, bijzonder opzet, gans bijzonder opzet, voorbedachtheid), waarop hier niet dieper zal worden ingegaan. ${ }^{100}$

26. Er is bepaald opzet (dolus determinatus) als de dader de handeling of het verzuim heeft gewild, alsook de gevolgen die hij precies kent. De dader wil een bepaald voorwerp stelen of hij wil een bepaalde persoon slaan en hij doet dat ook. Er is onbepaald opzet (dolus indeterminatus) als de dader de daad en de gevolgen wilde, zonder dat die gevolgen en hun omvang evenwel waren bepaald. Hij hield rekening met de gevolgen, die zich noodzakelijkerwijze of waarschijnlijk zouden voordoen, zonder evenwel precies te weten welke het juiste gevolg zou zijn. De dader plaatst een bom in een drukke winkelstraat wetende dat hij daarmee veel slachtoffers zal maken, zonder dat die slachtoffers bepaald zijn. Gemeenschappelijk aan het bepaald en het onbepaald gevolg is dat de dader zowel de gedraging als haar gevolgen heeft gewild en beide modaliteiten van opzet worden gezien als varianten van het rechtstreeks of direct opzet (dolus directus). ${ }^{\mathrm{II}}$

27. Bij onrechtstreeks of indirect opzet (dolus eventualis), ook eventueel opzet, mogelijk opzet of kansopzet genoemd ${ }^{142} /{ }^{143}$ heeft de dader de daad gewild, maar niet de gevolgen. De gevolgen zijn een ongewild neveneffect van de gedraging, maar de dader had die gevolgen voorzien en hij heeft ze erop de koop toegenomen of anders gezegd aan-

I37 Colette-Basecqz en Blaise, Manuel de droit pénal général, p. 27I; Van den Wyngaert, Strafrecht \& Strafprocesrecht 2011, p. 296 en 3 II.

I38 Cass. I6 oktober 1973, AC I974, I94; De Nauw, Inleiding tot het Algemeen Strafrecht 2010, p. 44, nr. 80 en p. 45, nr. 8I.

I39 De Nauw, Inleiding tot het Algemeen Strafrecht 2010, p. 45, nr. 8r.a); Dupont-Verstraeten, p. 248, nr. $4 \mathrm{I} 6$ en p. 249-250, nr. 420-422; C. Hennau en J. Verhaegen, bijgewerkt door D. Spielmann en A. Bruyndonkx, Droit pénal général, Brussel: Bruylant 2003, p. 317; nr. 345.d (hierna: HennauVerhaegen, Droit pénal général 2003); Van den Wyngaert, Strafrecht \& Strafprocesrecht 2011, p. 309.

I40 Dupont-Verstraeten, p. 25I-253, nr. 425-430.

I4I Colette-Basecqz en Blaise, Manuel de droit pénal général, p. 26I; De Nauw, Inleiding tot het Algemeen Strafrecht 2010, p. 46, nr. 8I.e) en f); Dupont-Verstraeten, p. 254-255, nr. 432-435; Van den Wyngaert, Strafrecht \& Strafprocesrecht 2011, p. 314; Vanhoudt-Calewaert, II, p. 337-338, nr. 656-657.

I42 Van den Wyngaert, Strafrecht \& Strafprocesrecht 2011, p. 3I4-3I5.

I43 In de rechtsleer (Colette-Basecqz en Blaise, Manuel de droit pénal général, p. 26I; Hennau-Verhaegen, Droit pénal général 2003, nr. 352-353) maken sommigen nog een onderscheid tussen onrechtstreeks opzet (waarbij de dader de zekere gevolgen aanvaardt) en eventueel opzet (waarbij de dader de mogelijke gevolgen aanvaardt). 
vaard. ${ }^{144}$ Het vooruitzicht van de gevolgen heeft de dader helemaal niet doen afzien van de daad die hij wilde stellen, zodat het gevolg onrechtstreeks aan zijn opzet wordt toegeschreven. ${ }^{\text {I5 }}$

28. Het Strafwetboek bevat diverse bepalingen waarbij de niet-gewilde gevolgen aan het opzet van de dader worden toegeschreven. Dat is onder meer het geval met de artikelen 347bis, $\$ 4,376$, 40 r tot 404, 4I7ter en quater, tweede lid, $2^{\circ}$ en 474 . Die misdrijven worden in de Franstalige literatuur praeter-intentionnelles genoemd. De dader heeft een eerste gevolg van het misdrijf wel gewild, maar niet een verder gevolg. ${ }^{\mathrm{I} 46}$ Er is samenloop van opzet en fout. ${ }^{\mathrm{I} 7}$ Typevoorbeeld is artikel $40 \mathrm{O}$ Sw.: ${ }^{\mathrm{I} 48}$ de dader heeft opzettelijk verwondingen toegebracht, maar het slachtoffer sterft zonder dat de dader dit oogmerk had. Deze misdrijven onderscheiden zich van het eventueel opzet, omdat de dader de gevolgen van zijn handeling niet aanvaardt, wat bij het eventueel opzet wel het geval is. ${ }^{\text {I49 }}$

\section{I.5. Het moreel bestanddeel: onachtzaamheid}

29. Het Strafwetboek bevat geen omschrijving van wat onachtzaamheid is. Volgens de cassatierechtspraak is een onachtzaamheidsmisdrijf een misdrijf dat erin bestaat dat de dader vrijwillig een handeling stelt waardoor een ongewild gevolg intreedt. ${ }^{150}$ De dader heeft weliswaar de daad of het verzuim gewild, maar niet de gevolgen ervan, ook al kon of moest hij die gevolgen voorzien en had hij die moeten vermijden. In dat opzicht is de term onopzettelijk misdrijf wat misleidend en wordt er beter van onachtzaamheidsmisdrijf (delictum culposum) gesproken. ${ }^{151}$

30. Sommigen in de rechtsleer ${ }^{152}$ en in de rechtspraak ${ }^{153}$ hanteren als synoniem voor onachtzaamheid ook fout. ${ }^{154}$ Fout wordt hier niet gebruikt in de betekenis van

I44 Over de precieze toepassingsvoorwaarden van het onrechtstreeks opzet bestaat in de rechtsleer nogal wat discussie (o.m. W. Brosens, 'Het morele bestanddeel der misdrijven en het toekomstige strafwetboek', RW I978-79, I8I5; Van den Wyngaert, Strafrecht \& Strafprocesrecht 2011, p. 317).

I45 De Nauw, Inleiding tot het Algemeen Strafrecht 2010, p. 46, nr. 8I.g); Dupont-Verstraeten, p. 255-256, nr. 437-438; Van den Wyngaert, Strafrecht \& Strafprocesrecht 2011, p. 315-316. Zie ook: J. Verhaegen, 'Le dol éventuel et sa place en droit pénal belge', in: Liber Amicorum Hermann Bekaert, Gent: SnoeckDecaju 1977, p. 437-452; J. Verhaegen, 'La définition de l'intention coupable dans les codes pénaux modernes', in: Liber Amicorum Frédéric Dumon, Antwerpen: Kluwer 1983, p. 529.

I46 Colette-Basecqz en Blaise, Manuel de droit pénal général, p. 265; Hennau-Verhaegen, Droit pénal général 2003, p. 349-350, nr. 400-402.

I47 Haus, Principes généraux du droit pénal, I, p. 238, nr. 329.

I48 Zie voor een toepassing: Corr. 27 februari 2008, JT 2008, 490, noot O. Michiels.

I49 Colette-Basecqz en Blaise, Manuel de droit pénal général, p. 266.

I50 Cass. 25 november 2008, P.08.088I.N, AC 2008, 2705.

I5I De Nauw, Inleiding tot het Algemeen Strafrecht 2010, p. 44, nr. 8o en p. 46, nr. 83; Dupont-Verstraeten, p. $248-249$, nr. 417 , p. 257 , nr. 440 en p. 258 , nr. 444 ; Vanhoudt-Calewaert, II, p. 309 , nr. 608 en p. $338-339$, nr. 660 .

I52 Vanhoudt-Calewaert, II, p. 26I, nr. 528.

I53 Bijv. Cass. 3I januari I989, AC I988-89, 648; Cass. I6 februari I993, AC I993, I93.

I54 B. Spriet, 'Elk misdrijf - ook dat uit het bijzonder strafrecht - vereist een moreel of schuldbestanddeel', lc, 535, nr. 8 . 
strafrechtelijke schuld of het plegen van een misdrijf zonder rechtvaardiging. ${ }^{155}$ In wat hierna volgt, moeten onachtzaamheid en fout of culpa als synoniemen worden begrepen.

3I. De rechtsleer maakt een onderscheid tussen de bewuste en de onbewuste onachtzaamheid. Bij onbewuste onachtzaamheid (onbewuste culpa of schuld, ook negligentia genoemd) is de dader er zich niet eens bewust van dat hij door zijn daad of verzuim het strafrechtelijk beschermd rechtsgoed krenkt, hoewel hij dat had moeten voorzien en vermijden. Bij bewuste onachtzaamheid (bewuste culpa of schuld, ook luxuria genoemd) is de dader zich er wel van bewust dat zijn daad of verzuim het beschermde rechtsgoed kan krenken, maar vertrouwt hij door een verkeerde inschatting van de situatie erop dat deze gevolgen zich niet zullen voordoen..$^{156}$

32. De in de praktijk meest toegepaste onachtzaamheidsmisdrijven zijn de onopzettelijke doding en de onopzettelijke slagen en verwondingen, strafbaar gesteld door de artikelen 4I8, 4I9 en 420 Sw., hierna gemakkelijkheidshalve de onopzettelijk letsel-misdrijven genoemd. Door de algemeenheid van hun omschrijving zijn deze strafbaarstellingen van toepassing op alle sectoren van het maatschappelijk leven $^{157}$ zoals verkeer en vervoer, sport, de medische wereld, de volksgezondheid, het consumentenrecht en de industrie. ${ }^{158}$

33. Het Strafwetboek bevat ook nog andere onachtzaamheidsmisdrijven, zoals de misdrijven strafbaar gesteld door:

- artikel I2oquinquies, dat bestraft hij die ingevolge nalatigheid voorwerpen die in het belang van 's lands veiligheid geheim moeten blijven laat vernietigen, ontvreemden of wegnemen;

- artikel 242, dat bij een ontvreemding of vernietiging van stukken, dragers of voorwerpen die zich in archieven, griffies of openbare bewaarplaatsen bevinden of die aan een openbaar bewaarder zijn toevertrouwd, de nalatige bewaarder bestraft;

- de artikelen 283 en 285 , die de nalatige bewaarder ingeval van zegelverbreking bestraffen;

- de artikelen 294 en 295, tweede lid, die hen die door nalatigheid leveringen aan het leger vertragen of doen mislukken bestraffen;

I55 F. Tulkens en M. Van de Kerchove, Introduction au droit pénal. Aspects juridiques et criminologiques, Brussel: Kluwer 2005, p. 390 (hierna: Tulkens en Van de Kerchove, Introduction au droit pénal).

I56 Colette-Basecqz en Blaise, Manuel de droit pénal général, p. 263; Dupont-Verstraeten, p. 258-259, nr. 445-446; Haus, Principes généraux du droit pénal, I, p. 236-237, nr. 326-327; Hennau-Verhaegen, Droit pénal général 2003, p. 34I, nr. 385; O. Michiels, 'Quelques précisions sur les notions de faute, de dol éventuel et de dol praeter-intentionnel quand il y a mort d'homme', (noot onder Corr. Verviers 27 februari 2008), l.c., 492, nr. 3 .

I57 S. Van Overbeke, 'De arts in de beklaagdenbank. De medische fout deskundig en strafrechtelijk ge(dis)kwalificeerd', in: F. De Ruyck en M. Rozie (red.), Liber Amicorum Alain De Nauw. Het strafrecht bedreven, Brugge: Die Keure 20II, p. 922.

I58 J. Spreutels, F. Roggen en E. Roger France, Droit pénal des affaires, Brussel: Bruylant 2005, p. 946 (hierna: Spreutels, Roggen en Roger France, Droit pénal des affaires). 
- de artikelen 333,334 en 336 , die de nalatige bewakers ingeval van ontvluchting van gevangenen bestraffen;

- artikel 519, dat de dader van een onopzettelijke brandstichting bestraft.

Bijzondere strafwetten bestraffen soms uitdrukkelijk onachtzaamheid of ze bestraffen zowel het opzettelijk als het uit onachtzaamheid handelen, zij het dat soms opzettelijk handelen zwaarder wordt gestraft. Dat is onder meer het geval met de Vlaamse milieuhandhavingsregelgeving. ${ }^{159}$

34. Hierboven werd aangegeven dat voor wanbedrijven uit de bijzondere strafwetten en voor overtredingen bij gebrek aan een wettelijk bepaald moreel bestanddeel in de regel onachtzaamheid een voldoende schuldvorm is. Die onachtzaamheid verschilt inhoudelijk niet van het uitdrukkelijk aangegeven moreel bestanddeel van het gemeenrechtelijk onopzettelijk misdrijf. ${ }^{60}$

35. In het volgende deel wordt de wijze besproken waarop de rechtspraak het begrip onachtzaamheid met betrekking tot de onopzettelijk letsel-misdrijven invult. Wat hieromtrent wordt geschreven, geldt in de regel evenzeer voor de andere onachtzaamheidsmisdrijven.

\section{De voor de onopzettelijke doding en onopzettelijke slagen en verwondingen vereiste onachtzaamheid}

\section{I. De wetsgeschiedenis}

36. De artikelen $4 \mathrm{I} 8$ tot en met $420 \mathrm{Sw}$. zijn in ruime mate geïnspireerd door de artikelen 3 I9 en 320 van de Franse Code pénal van I8Io, met de volgende inhoud:

'Article 319. Quiconque, par maladresse, imprudence, inattention, négligence ou inobservation des règlements, aura commis involontairement un homicide, ou en aura involontairement étéla cause, sera puni d'un emprisonnement de trois mois à deux ans, et d'une amende de cinquante francs à six cents francs.

Article 320. S'il n'est résulté du défaut d'adresse ou de précaution que des blessures ou coups, l'emprisonnement sera de six jours à deux mois,et l'amende sera de seize francs à cents francs.'

37. De tekst van de artikelen 4I8-420 Sw. luidde bij de inwerkingtreding van het Belgisch Strafwetboek van 1867 als volgt:

I59 Volgens het Vlaamse decreet van 5 april 1995 zijn sommige milieu-inbreuken alleen maar strafbaar bij opzet (art. I6.6.I, § 2 en I6.6.3bis), worden andere op dezelfde wijze gestraft ongeacht of er opzettelijk of door onachtzaamheid werd gehandeld (art. I6.6.I., § I, I6.6.3sexies en I6.6.3 septies) en bestaat voor nog andere een verschil in bestraffing naargelang ze opzettelijk of uit onachtzaamheid werden begaan (art. I6.6.2., § I, I6.6.3., § I en I6.6.3ter, quater en quinquies).

I6o B. Spriet, 'Elk misdrijf - ook dat uit het bijzonder strafrecht - vereist een moreel of schuldbestanddeel', l.c, 535, nr. 9 . 
'Art. 418. Est coupable d'homicide ou de lésion involontaires, celui qui a causéle mal par défaut de prévoyance ou de précaution, mais sans intention d'attenter à la personne d'autrui.

Art. 419. Quiconque aura involontairement causéla mort d'une personne sera puni d'un emprisonnement de trois mois à deux ans et d'une amende de cinquante francs à mille francs.

Art. 420. S'il n'est résulté du défaut de prévoyance ou de précaution que des coups ou des blessures, le coupable sera puni d'un emprisonnement de huit jour à deux mois et d'une amende de cinquante francs à cinq cents francs, ou d'une de ces peines seulement.'

38. Met artikel I van de Wet van 3I maart 1936 werd de door artikel 420 Sw. bepaalde maximumgevangenisstraf opgetrokken van twee tot zes maanden. Een maximumstraf van twee maanden was volgens de parketten, daarin gevolgd door de regering, in het licht van het stijgend aantal motorvoertuigen en ongevallen ontoereikend. De straf werd als niet aangepast beschouwd bij ongevallen met ernstige verwondingen, zeker indien ook de schuld van de dader zwaarwichtig was (bijvoorbeeld dronken sturen). Een dergelijke straf liet bovendien geen aanhoudingsbevel toe, wat ter ontdekking van de waarheid soms noodzakelijk werd geacht. ${ }^{16 \mathrm{I}}$ De Kamercommissie voor Justitie vond de voorgestelde strafverzwaring slechts in twee gevallen gerechtvaardigd, namelijk indien het ongeval een blijvende arbeidsongeschiktheid of het verlies van een orgaan of een zware verminking had veroorzaakt en indien de slagen of verwondingen het gevolg waren van een grove schuld. Met grove schuld werd de niet te vergeven onvoorzichtigheid bedoeld, de aan het opzet grenzende schuld (culpa dolo proxima). Een verstrenging voor de door lichte onvoorzichtigheid veroorzaakte kleine letsels vond de Kamercommissie niet nodig. ${ }^{162}$ Het voorstel van de Kamercommissie werd uiteindelijk ingetrokken omdat het tot te veel praktische moeilijkheden zou leiden en het aanvankelijk voorstel werd goedgekeurd. Er werd benadrukt dat de rechter de maximumstraf niet diende op te leggen en dat hij voor wat onbeduidende delicten werd genoemd, zijnde de ongevallen met weinig ernstig letsel of veroorzaakt door een lichte onvoorzichtigheid, de ongewijzigd gebleven minimumstraffen kon opleggen. ${ }^{163}$

39. Bij de vaststelling van de Nederlandse tekst van het Strafwetboek bij de Wet van Io juli 1964 , luidde de tekst van de artikelen 418-420 Sw. als volgt:

Art. 418. Schuldig aan onopzettelijke doden of aan onopzettelijk toebrengen van letsel is hij die het kwaad veroorzaakt door gebrek aan voorzichtigheid of voorzorg, maar zonder het oogmerk om de persoon van een ander aan te randen.

Art. 419. Hij die onopzettelijk iemands dood veroorzaakt, wordt gestraft met gevangenisstraf van drie maanden tot twee jaar en met geldboete van vijftig frank tot duizend frank.

Art. 420. Indien het gebrek aan voorzichtigheid of voorzorg alleen slagen of verwondingen ten gevolge heeft, wordt de schuldige gestraft met gevangenisstraf van acht dagen tot zes maanden en met geldboete van vijftig frank tot vijfhonderd frank of met een van die straffen alleen.'

I6I Parl. St. Kamer, I935-36, nr. 63, I-2; Parl. Hand. Kamer, 3 maart I936, 697.

I62 Parl. St. Kamer, I935-36, nr. 99, I.

I63 Parl. St. Senaat, I935-36, nr. II9, 2. 
40. De Wet van 7 februari 2003 houdende verschillende bepalingen inzake verkeersveiligheid voerde met ingang van I maart 2004 een art. 4Igbis en een art. 420 bis in het Strafwetboek in:

Art. 41gbis. Met een gevangenisstraf van 3 maanden tot 5 jaar en met geldboete van 50 euro tot 2.000 euro of met een van die straffen alleen, wordt gestraft, elke weggebruiker die door gebrek aan voorzichtigheid of voorzorg een verkeersongeval veroorzaakt dat iemands dood tot gevolg heeft.

Art. 42obis. Met gevangenisstraf van acht dagen tot een jaar en met geldboete van 50 euro tot 1.000 euro of met een van die straffen alleen, wordt gestraft, elke weggebruiker die door gebrek aan voorzichtigheid of voorzorg een verkeersongeval veroorzaakt dat slagen of verwondingen tot gevolg heeft.

4I. Met het opleggen van opmerkelijk zwaardere straffen voor onopzettelijke doding, slagen en verwondingen bij een verkeersongeval wilde de wetgever de doelstelling realiseren het aantal verkeersslachtoffers drastisch terug te dringen. ${ }^{164}$

42. Uit de parlementaire voorbereiding blijkt dat deze vorm van verzwarende omstandigheid van toepassing was voor 'gelijk welk gevaarlijk of onachtzaam rijgedrag' dat heeft geleid tot de dood, slagen en verwondingen van een weggebruiker. ${ }^{165}$ Aan de vereiste van het gebrek aan voorzichtigheid of voorzorg werd dus niets gewijzigd.

43. Een parlementslid kon zich niet vinden in deze strafverzwaring. Hij wees erop dat het gebrek aan voorzichtigheid of voorzorg van de artikelen 4I8-420 Sw. volgens de rechtspraak van het Hof van Cassatie overeenkomt met de nalatigheid en onvoorzichtigheid van de artikelen ${ }_{13} 82$ e.v. Burgerlijk Wetboek en dus alle vormen van fout omvat met inbegrip van de kleine fouten, foutbegrip dat soeverein door de rechter wordt ingevuld. Het parlementslid vond de strafbepalingen te ruim toepasbaar en zag geen meerwaarde in de voorgestelde strafverzwaring, die hij buiten proportie achtte. Met de voorgestelde strafverzwaring zou onopzettelijk letsel zwaarder worden gestraft dan sommige gevallen van opzettelijk letsel en de straffen zouden niet alleen van toepassing zijn op chauffeurs, maar ook op zwakke weggebruikers die een fout begaan. Andere parlementsleden achtten dan weer de in artikel $420 b i$ Sw. voorgestelde maximumstraf te laag en stelden voor die op te trekken tot twee jaar. Ze wilden dat de rechter extreem zware overtredingen die leiden tot zware definitieve letsels in verhouding relatief streng genoeg kon straffen. ${ }^{166}$ De Minister, die de strafverzwaring zag als een tussenweg tussen de gewone onopzettelijke slagen en verwondingen (art. 420 Sw.) en het misdrijf van kwaadwillige verkeersbelemmering (art. 406-408 Sw.), pleitte voor vertrouwen in de rechterlijke macht. Hij voerde aan dat de rechter rekening kan houden met de omstandigheden waarin de bestuur-

I64 T. Papart, 'Le droit de circulation', in: A. Jacobs (red.), Actualités de droit pénal et de procédure pénale (II), Brussel: Larcier 2004, p. 31.

I65 Parl. St. Kamer, 200I-02, 50-I9I5/00I, 2 I.

I66 Parl. St. Kamer, 200I-02, 50-I9I5/005, 38; Parl. St. Senaat, 2002-03, 2-I402/2, 22 en 2-I402/3, 54. 
der het ongeval veroorzaakte (rijden onder invloed; rijden met een buitengewone snelheid, enzovoort) en met de toestand van het slachtoffer. ${ }^{167}$ Het parlement volgde de Minister.

44. Met de Wet van 20 juli 2005 tot wijziging van de gecoördineerde wetten van I6 maart I968 betreffende de politie over het wegverkeer werden de artikelen 4Igbis en 420 bis Sw. opgeheven en de quasi gelijkluidende tekst ${ }^{168}$ ervan geïntegreerd in het Strafwetboek als een tweede lid van de artikelen 4 I9 en 420 Sw. Tijdens de parlementaire bespreking van deze wetswijziging werd de in 2003 ingevoerde strafverzwaring, zij het tevergeefs, aan de orde gesteld en werd voorgesteld om de met artikel 42obis, thans artikel 420, tweede lid, Sw. ingevoerde strafverzwaring te schrappen. Het werd niet verantwoord geacht dat ongevallen die te wijten zijn aan een gebrek aan voorzichtigheid of voorzorg, dus zonder ernstige fout, waarbij slechts lichtgewonden vallen, zo zwaar konden worden gestraft. ${ }^{169}$

45. Vanaf 3 I maart 2006 en tot op heden bepalen de artikelen $4 \mathrm{I} 8$ tot en met 420 Sw.:

Art. 418. Schuldig aan onopzettelijk doden of aan onopzettelijk toebrengen van letsel is hij die het kwaad heeft veroorzaakt door gebrek aan voorzichtigheid of voorzorg, maar zonder het oogmerk om de persoon van een ander aan te randen.

Art. 419. Hij die onopzettelijk iemands dood veroorzaakt, wordt gestraft met gevangenisstraf van drie maanden tot twee jaar en met geldboete van vijftig frank tot duizend frank.

Wanneer de doding het gevolg is van een verkeersongeval dan bedraagt de gevangenisstraf drie maanden tot vijfjaar en de geldboete 50 euro tot 2.000 euro.

Art. 420. Indien het gebrek aan voorzichtigheid of voorzorg alleen slagen of verwondingen ten gevolge heeft, wordt de schuldige gestraft met gevangenisstraf van acht tot zes maanden en met geldboete van vijftig frank tot vijfhonderd frank of met een van die straffen alleen.

Wanneer de slagen of verwondingen het gevolg zijn van een verkeersongeval dan bedraagt de gevangenisstraf acht dagen tot een jaar en de geldboete 50 euro tot 1.000 euro.

46. Men kan zich afvragen of het verschil in bestraffing tussen de onopzettelijk letsel-misdrijven in verkeersverband en die daarbuiten wel door de beugel kan in het licht van het gelijkheid- en non-discriminatiebeginsel. ${ }^{170}$ Is er een verantwoording te bedenken om de veroorzaker van een dodelijk verkeersongeval zwaarder te bestraffen dan bijvoorbeeld de veroorzaker van een dodelijk arbeidsongeval? Het College van procureurs-generaal had overigens voorgesteld om de strafmaat van de artikelen $4 \mathrm{I} 9$ en $420 \mathrm{Sw}$. in het algemeen te verhogen en dus zonder de strafverzwaring te beperken tot de verkeerscontext. ${ }^{171}$ Hoewel het Grondwettelijk Hof zich over

I67 Parl. St. Senaat, 2002-03, 2-I402/3, 34 .

I68 Anders dan in art. 4Igbis is de rechter met art. 4I9, tweede lid, verplicht om zowel een gevangenisstraf als een geldboete op te leggen, tenzij hij verzachtende omstandigheden aanneemt.

I69 Parl. St. Kamer, 2004-05, 5I-I428/006, 5.

I70 Spreutels, Roggen en Roger France, Droit pénal des affaires, p. 946, noot (2817).

I7I Omzendbrief R nr. 05/04 van 3 februari 2004 van de procureur-generaal te Gent, p. 2; Omzendbrief R nr. II/2006 van Io april 2006 van de procureur-generaal te Gent, p. 3. 
deze aangelegenheid nog niet uitdrukkelijk heeft uitgesproken, blijkt uit zijn recht$\operatorname{spraak}^{172}$ omtrent de nieuwe verkeerswetgeving dat de betrachting van de wetgever om door een strengere bestraffing een einde te maken aan de stijging van het aantal slachtoffers van verkeersongevallen, een aanvaardbare verantwoording voor het verschil in behandeling zou kunnen zijn.

\subsection{Tussen toeval en opzet}

47. De onopzettelijke letsel-misdrijven situeren zich tussen het door louter toeval veroorzaakte letsel en het (eventueel) opzettelijk veroorzaakte letsel. ${ }^{173}$ In het eerste geval, dat niet tot het domein van het strafrecht behoort, ${ }^{174}$ is het schuldbegrip niet aan de orde. In het tweede geval vormt (eventueel) opzet het moreel bestanddeel. ${ }^{175}$

48. Het moreel bestanddeel van de onopzettelijk letsel-misdrijven bevat een negatief element. Volgens artikel 4I8 Sw. mag er geen oogmerk zijn om de persoon van een ander aan te randen. De dader mag niet hebben gehandeld met de bedoeling iemand enig lichamelijk leed te bezorgen. ${ }^{176}$ Weliswaar is er in de Nederlandse tekst van artikel $4 \mathrm{I} 8$ als gevolg van een onvolmaakte vertaling uit het Frans sprake van 'het toebrengen' van letsels, maar daaruit mag geen intentionaliteit worden afgeleid. ${ }^{177} \mathrm{De}$ afwezigheid van het oogmerk om andermans persoon aan te randen onderscheidt deze misdrijven van de opzettelijke doding en de opzettelijke slagen of verwondingen bedoeld door de artikelen 392 e.v. Sw. ${ }^{178}$

49. In de Franse tekst van het opschrift van hoofdstuk II van titel VIII van het Strafwetboek en in de artikelen 4I8 en 4I9 wordt het begrip 'involontaires' en 'involontairement' gehanteerd. Dit werd tot ${ }^{2} 644$ in de niet-authentieke Nederlandstalige versie vertaald als 'onvrijwillig'. 'Onvrijwillig' zou de indruk kunnen wekken dat er bij de dader geen enkele wil mag bestaan, doch dit is onjuist. Ook onopzettelijke misdrijven zijn slechts strafbaar indien ze het gevolg zijn van een gewilde en dus zonder dwang of noodzaak gestelde handeling of verzuim, zij het met een niet gewild en niet voorzien gevolg. ${ }^{179}$ Vandaar dat het correcter is in het Nederlands het

I72 Arbitragehof nr. 57/2007, I8 april 2007, B.2.2-B.2.4.

I73 Vanhoudt-Calewaert, II, p. 333-334, nr. 648 en p. 339-340, nr. 662.

I74 De Code pénal van I79i bepaalde uitdrukkelijk dat een onopzettelijke doding als gevolg van een ongeval en zonder dat enige onachtzaamheid of onvoorzichtigheid was bewezen geen misdaad was en geen aanleiding kon geven tot enige straf of civielrechtelijke veroordeling (J. Nypels en J. Servais, Le code pénal belge interprété principalement au point de vue de la pratique, III, Brussel: Bruylant I898, p. II4, voetnoot (I), hierna geciteerd als Nypels-Servais, Le code pénal belge interprété, III).

I75 De Nauw, Inleiding tot het Algemeen Strafrecht 2010, p. 47, nr. 85; Nypels-Servais, Le code pénal belge interprété, III, p. II4, nr. I.

I76 R. Declercq, 'Enkele problemen i.v.m. de toepassing van de artikelen 4I8, 4I9 en 420 van het Strafwetboek', in: Bijzonder strafrecht voor rechtspractici, Leuven: Acco I99o, p. I93.

I77 R. Declercq, 'Enkele problemen i.v.m. de toepassing van de artikelen 4I8, 4I9 en 420 van het Strafwetboek', l.c., p. I93.

I78 Bergen 8 februari I985, JT I985, 593; Jeugdrb. Dinant 25 april I973, Pas. I974, III, 2.

I79 Jeugdrb. Dinant 25 april I973, Pas. I974, III, 2; De Nauw, Inleiding tot het Algemeen Strafrecht 2010, p. 43, nr. 79.a; R. Declercq, 'Enkele problemen i.v.m. de toepassing van de artikelen 4I8, 4I9 en 
begrip 'onopzettelijk' te gebruiken, zoals dit gebeurde met de door de wet van to juli I964 goedgekeurde authentieke Nederlandse versie, en in het Frans de term 'non intentionnel' in plaats van 'involontaire', een term die nochtans in de Franstalige authentieke versie is behouden. ${ }^{180}$

\subsection{De onachtzaamheid}

50. In artikel 3 I9 Code Pénal van I8Io, als voorloper van artikel 4 I8 Sw., werd melding gemaakt van 'la maladresse, l'imprudence, l'inattention, la négligence et l'inobservation des réglements'. Opdat er een misdrijf zou zijn, diende een van vijf omstandigheden aanwezig te zijn. ${ }^{18 \mathrm{r}} \mathrm{De}$ uitdrukking 'par défaut d'adresse ou de précaution' van artikel 320 Code Pénal van i8ro omvatte deze vijf omstandigheden, waarbij 'le défaut d'adresse' was gelijk te stellen met 'la maladresse' en met 'le défaut de précuation' 'l'imprudence, l'inattention, la négligence et l'inobservation des règlements' overeenkwam. ${ }^{\mathrm{I} 2 \mathrm{2}}$

5I. Uit de parlementaire voorbereiding van het Strafwetboek van I867 blijkt dat de wetgever naast de reeds in de artikelen 319 en 320 Code Pénal van I8Io vermelde tekortkomingen, ook nog andere verschijningsvormen van fout zag, zoals 'l'ignorance de l'art ou de la profession qu'exerce l'agent, l'imprevoyance, l'insouciance, la paresse, la témérité, la pétulance'. Met de uitdrukking gebrek aan voorzichtigheid of voorzorg beoogde hij alle gevallen van strafbare fout of met andere woorden elke fout met als resultaat een lichamelijk letsel. ${ }^{183}$ De vermelde verschijningsvormen van fout zijn dan ook slechts nuances van onachtzaamheid als enig moreel bestanddeel van de onopzettelijk letsel-misdrijven. ${ }^{184}$

\subsection{Het gebrek aan voorzichtigheid of voorzorg}

52. De strafwetgever heeft met de artikelen 418 en 420 Sw. de onachtzaamheid omschreven als het gebrek aan voorzichtigheid of voorzorg. In de rechtsleer wordt op basis van de parlementaire voorbereiding het volgende onderscheid gemaakt. Er is een gebrek aan voorzichtigheid wanneer de dader handelt of verzuimt, zonder zich daarvan de mogelijke gevolgen te realiseren of daarvan een verkeerde voorstelling van zaken geeft, ofschoon hij die gevolgen had kunnen en moeten voorzien om ze te vermijden. ${ }^{185} \mathrm{Er}$ is een gebrek aan voorzorg wanneer de dader handelt of ver-

420 van het Strafwetboek', l.c., p. I93; Nypels-Servais, Le code pénal belge interprété, III, p. II4, nr. I en voetnoot (2).

I80 De Nauw, Bijzonder strafrecht 2010, p. 2I6, nr. 268; Van den Wyngaert, Strafrecht \& Strafprocesrecht 2011, p. 309; Vanhoudt-Calewaert, II, p. 309-310, nr. 608.

I8I Nypels-Servais, Le code pénal belge interprété, III, p. II5, nr. 3 en voetnoot (3).

I82 Nypels-Servais, Le code pénal belge interprété, III, p. II5, nr. 3.

I83 J. Nypels, Législation criminelle de la Belgique ou commentaire et complément du Code pénal belge, III, Brussel: Bruylant I868, p. 24I, nr. I04 in fine en nr. Io5 en p. 242, nr. Io6 (hierna: Nypels, Législation criminelle, III); Nypels-Servais, Le code pénal belge interprété, III, p. II8 nr. 7.

I84 Nypels-Servais, Le code pénal belge interprété, III, p. II5, nr. 3.

I85 De Nauw, Inleiding tot het Algemeen Strafrecht 2010, p. 47, nr. 84; Dupont-Verstraeten, p. 257, nr. 44I.a); Haus, Principes généraux du droit pénal belge, II, p. 236-237, nr. 326-327; Nypels-Servais, 
zuimt, zonder er zorg voor te dragen dat de mogelijk daarmee verbonden nadelige gevolgen zullen optreden, alhoewel hij in staat was deze gevolgen te vermijden. De dader heeft aan de gevolgen gedacht, maar rekende erop dat die zich niet zouden voordoen ofschoon hij beter kon en moest weten. ${ }^{186}$ Aangezien het voor strafbaarheid geen verschil maakt of de dader een gebrek aan voorzichtigheid dan wel aan voorzorg aan de dag legde, komt dit onderscheid in de rechtspraktijk nauwelijks aan bod.

\subsection{Elke fout}

53. Uit de parlementaire voorbereiding van het Strafwetboek blijkt dat elke fout die onopzettelijk aanleiding geeft tot lichamelijk letsel tot de toepassing van de artikelen $418-420$ Sw. leidt. Het Hof van Cassatie ${ }^{187}$ en de feitenrechters ${ }^{188}$ zijn die regel steeds getrouw gebleven. De fout kan bestaan in een onthouding of in een positieve daad. ${ }^{189}$ De fout kan een inbreuk zijn op een al dan niet strafrechtelijk gesanctioneerde wettelijke of reglementaire bepaling, die eventueel afzonderlijk aan de beklaagde wordt ten laste gelegd, maar dit hoeft niet. ${ }^{190}$

\subsection{De identiteit tussen de strafrechtelijke en de burgerrechtelijke fout}

54. Volgens de rechtspraak stemt een fout in de zin van de artikelen 4I8, 4I9 en 420 Sw. overeen met de fout van de artikelen $\mathrm{I}_{3} 82$ en $\mathrm{I}_{3} 83 \mathrm{BW}$. Het Hof van Cassatie heeft aan het einde van de negentiende eeuw ${ }^{191}$ die stelling aangenomen en ze daarna herhaaldelijk bevestigd, ${ }^{192}$ daarin gevolgd door de feitenrechters. ${ }^{193}$ De onachtzaamheid als moreel bestanddeel van deze misdrijven ${ }^{194}$ wordt dus gelijkgesteld met het

Le code pénal belge interprété, III, p. II6, nr. 4; Vanhoudt-Calewaert, II, p. 339, nr. 66I.

I86 De Nauw, Inleiding tot het Algemeen Strafrecht 2010, p. 47, nr. 84; Dupont-Verstraeten, p. 257, nr. 442.b); Nypels-Servais, Le code pénal belge interprété, III, p. II6, nr. 4; Vanhoudt-Calewaert, II, p. 339 , nr. 66r.

I87 Cass. I7 juli I884, Pas. I884, I, 275; Cass. 5 oktober I893, Pas. I893, I, 32I; Cass. 5 oktober I893, Pas. I893, I, 328; Cass. 29 januari I923, Pas. I923, I, I73; Cass. I3 januari I927, Pas. I927, I, I22; Cass. 3I mei 2000, P.00.0235.F, AC 2000, IOI7; Cass. I2 september 2007, P.07.0804.F, AC 2007, I603.

I88 Brussel I7 oktober I969, RW I969-70, 474; Antwerpen 22 november I990, Vl. T. Gez. I993-94, I48; Corr. Leuven 5 december I93I, RGAR I934, nr. I456; Corr. Brugge 6 maart I937, Pas. I937, III, II; Pol. Leuze 13 januari 1961, De Verz. 1963, 592.

I89 Cass. 23 november I93I, Pas. I93I, I, 29I, concl. A. Gesche; Corr. Brugge 6 maart I937, Pas. I937, III, II.

I90 O.m. Cass. 24 mei 1937, AC I937, 48; Cass. 4 november 1997, P.95.0907.N, AC 1997, I07I.

I9I Cass. I7 juli I884, Pas. I884, I, 275; Cass. 5 oktober I893, Pas. I893, I, 32I; Cass. 5 oktober I893, Pas. I893, I, 328; Cass. 4 maart I894, Pas. I894, I, I32. Zie ook: Cass. I februari I877, Pas. I877, I, 92 ;

I92 O.m. Cass. I5 december I958, AC I959, 328; Cass.I2 december I968, AC I969, 373; Cass. I9 februari I988, AC I987-88, 795; Cass. 26 oktober I990, AC I990-91, 244. Zie ook Arbitragehof nr. 47/2002, I3 maart 2002, B.4.2.

I93 O.m. Gent I6 oktober 2003, RGAR 2005, nr. I4.oro; Corr. Brugge 6 maart I937, Pas.I938, III, II; Corr. Luik 27 november I963, JT I964, I30; Corr. Luik 2 maart I965, JT I965, 624; Corr. Leuven 20 mei 2003, T. Gez. 2004-05, 228; Pol. Leuze iz januari ig6r, De Verz. I963, 592.

I94 De regel van de eenheid van fouten zou niet gelden voor misdrijven waar de wetgever heeft bepaald dat enkel bepaalde vormen van onachtzaamheid tot strafbaarheid leiden, zoals dit het 
schuldbegrip van artikel 1382 BW. ${ }^{195}$ Volgens R. Declercq ${ }^{196}$ is overeenstemmen te zacht uitgedrukt, maar gaat het om een absolute identiteit, ongeacht of de burgerlijke fout quasidelictueel dan wel contractueel van aard is. De omstandigheid dat een strafbaar feit wordt gepleegd bij de uitvoering van een overeenkomst staat overigens de toepassing van de strafwet of van de regels omtrent de uit een misdrijf voortvloeiende burgerlijke aansprakelijkheid niet in de weg. ${ }^{197}$

55. Uit die assimilatie volgt evenwel niet dat de artikelen 4I8-420 Sw. moeten worden beschouwd als een algemene strafbaarstelling van alle burgerrechtelijke fouten of nalatigheden die de artikelen $\mathrm{I}_{3} 82$ en $\mathrm{I}_{3} 83 \mathrm{BW}$ beogen. De voormelde strafbepalingen beschermen alleen tegen fouten die lichamelijke schade veroorzaken. Schade die niet bestaat in een aantasting van de fysieke integriteit valt niet onder deze strafbepalingen. Identiteit van foutbegrip wordt niet doorgetrokken tot identiteit van schadebegrip. ${ }^{198}$ Dit belet nochtans niet dat indien het onopzettelijk letsel-misdrijf ook materiële schade heeft veroorzaakt de schadelijder daarvoor op grond van dit misdrijf vergoeding kan vorderen voor de strafrechter. ${ }^{\text {I99 }}$

\subsection{De vereiste van een persoonlijke fout}

56. Een schuldigverklaring aan een onopzettelijk letsel-misdrijf is enkel mogelijk indien in hoofde van de beklaagde een persoonlijke fout wordt aangetoond. ${ }^{200} \mathrm{De}$ beklaagde kan niet strafrechtelijk verantwoordelijk worden gesteld voor de onachtzaamheid van een ander, tenzij zou blijken dat die onachtzaamheid een gevolg is van zijn eigen onachtzaamheid, bijvoorbeeld door een gebrek aan toezicht. ${ }^{20 r}$

57. Uit de regel van de identiteit van fouten volgt niet dat de bepalingen van het Burgerlijk Wetboek die in hoofde van bepaalde personen een vermoeden van fout in het leven roepen, doorwerking krijgen op strafrechtelijk gebied. Het door de artikelen

geval is met de onopzettelijke brandstichting van art. 519 Sw. (R. Dalcq, Traité de la responsabilité civile, I, Les causes de responsabilité, in: Les Novelles. Droit Civil, V/I, Brussel: Larcier 1959, p. I63, nr. 300; R. Dalcq, 'Faute civile et faute pénale ...', l.c., p. 75).

I95 De Nauw, Inleiding tot het Algemeen Strafrecht 2010, p. 47, nr. 86.

I96 R. Declercq, 'Enkele problemen i.v.m. de toepassing van de artikelen 4I8, 4I9 en 420 van het Strafwetboek', l.c., p. 194 en noot (27).

I97 O.m. Cass. 26 oktober I990, AC I990-9I, 244; Gent 9 januari I96o, Pas. I960, II, I92; Spreutels, Roggen en Roger France, Droit pénal des affaires, p. 946.

I98 S. Van Overbeke, 'Onopzettelijke doodslag en onopzettelijke slagen en verwondingen: een algemene strafbaarstelling die een specifieke schade onderstelt', (noot onder Cass. I februari 20II), RW 20II-I2, 958, nr. 3; S. Van Overbeke, 'De arts in de beklaagdenbank. ..., l.c., p. 925.

I99 O.m. Cass. 22 november 2000, P.o0.1173.F, AC 2000, I820; R. Declercq, Beginselen van strafrechtspleging, Mechelen: Kluwer 20I0, p. I226, nr. 2972.

200 Luik I8 juni I88I, Pas. I88I, II, 353; Luik I9 maart I959, Rev. dr. pén. I958-59, 805; Corr. Brussel 5 april i909, Rev. dr. pén. I909, 487.

201 J. Du Jardin, Concl. bij Cass. 23 januari I99I, Rev. dr. pén. I992, 315; C. Hennau-Hublet, 'L'action civile fondée sur le délit de coups et blessures par imprudence', (noot onder Cass. 23 januari I99I), RGAR I992, II.938/2 verso; C. Hennau-Hublet, 'La responsabilité pénale pour coups et bléssures involontaires en raison d'un comportement d'omission', (noot onder Cass. 23 januari I99I, Rev. dr. pén. 1992, 328). 
I384, I385 en I386 Burgerlijk Wetboek gecreëerde foutvermoeden in hoofde van de bewaarder van de zaak, de ouder voor de door zijn minderjarig kind veroorzaakte schade, de meester en de aansteller voor de door zijn dienstbode of aangestelde veroorzaakte schade, de onderwijzer of de ambachtsman voor de door zijn leerling of leerjongen veroorzaakte schade, de eigenaar of de gebruiker van door een dier veroorzaakte schade en de eigenaar voor schade veroorzaakt door de instorting van zijn gebouw, zijn bij de beoordeling van het gebrek aan voorzichtigheid of voorzorg in de zin van de artikelen $4 \mathrm{I} 8-420 \mathrm{Sw}$. niet relevant. ${ }^{202}$ Dat geldt ook voor de in de artikelen 1792 en 2270 BW voor aannemers en architecten bepaalde civiele aansprakelijkheidregels. ${ }^{203}$

58. De eigenaar of de gebruiker van een hond die een derde verwondt en die bij toepassing van artikel $\mathrm{I}_{3} 85 \mathrm{BW}$ civielrechtelijk aansprakelijk is voor de door de hond veroorzaakte schade, kan op die enkele grond niet strafrechtelijk worden veroordeeld wegens het onopzettelijk toebrengen van slagen of verwondingen. Dit kan wel als wordt aangetoond dat hijzelf een fout heeft begaan, bijvoorbeeld door een gevaarlijke hond zonder leiband op de openbare weg te laten lopen ${ }^{204}$ of door geen maatregelen te hebben genomen om te vermijden dat de hond op de openbare weg het verkeer zou hinderen. ${ }^{205}$ Het gebruik van een gebrekkige zaak, waarvan kan en diende te worden voorzien dat dit voor de gebruiker schade kon veroorzaken, kan een fout vormen in de zin van de artikelen 4I8-420 Sw. ${ }^{206}$

\subsection{Eerste mogelijkheid: de fout bestaat in de overtreding van een wel bepaald gebod of verbod}

59. Zoals reeds aangegeven kan de fout bestaan in de niet-naleving van een al dan niet strafrechtelijke gesanctioneerde specifieke rechtsnorm. ${ }^{207}$ Elke niet-naleving van een dergelijk verbod of gebodsbepaling of met andere woorden van een resultaatsverplichting levert een fout op, zonder dat enige zorgvuldigheidsappreciatie moeten worden gemaakt.

6o. De overheid heeft in de meest diverse domeinen van het maatschappelijk verkeer regels uitgevaardigd die tot doel hebben dat verkeer op een ordentelijke wijze te laten verlopen en desgevallend om het risico op schade in het algemeen en lichamelijk letsel in het bijzonder uit te sluiten of te beperken. Indien de niet-naleving

202 Bijv. Pol. Bossu ro april I953, T. Vred. I954, 292; Pol. Mechelen 27 december ig63, T. Vred. I964, 62; Cloquette, Concl. bij Cass. 2 februari $186_{3}$, Pas. I863, I, 105.

203 R. Declercq, 'Enkele problemen i.v.m. de toepassing van de artikelen 4I8, 4I9 en 420 van het Strafwetboek', l.c., p. 201.

204 O.m. Brussel I2 maart I985, RW I986-87, 262, noot A. Vandeplas; Corr. Oudenaarde 23 mei I946, RW I946-47, 979; H. Bosly, 'Les homicides et lésions corporelles non intentionnels', in: Les infractions, 2, Les infractions contre les personnes, Brussel: Larcier 2010, p. 509.

205 Pol. Leuze I3 januari ig6r, De Verz. I963, 592.

206 Brussel 4 januari I952, JT I952, 502.

207 Constant, Manuel de Droit Pénal, II, p. 205-207, nr. I083-Io85. 
van een dergelijk gebod of verbod heeft geleid tot lichamelijk letsel dan vormt die niet-naleving de voor het onopzettelijk letsel-misdrijven vereiste fout.

6r. Een inbreuk op de verkeersreglementering kan evident de voor de onopzettelijk letsel-misdrijven vereiste fout uitmaken, ongeacht of die als afzonderlijke inbreuk aan de dader werd ten laste gelegd. ${ }^{208}$ De rechter neemt bij de beoordeling van de fout in voorkomend geval ook alle overtredingen van het Wegverkeersreglement of de Wegverkeerswet in aanmerking, ongeacht of die overtredingen afzonderlijk worden ten laste gelegd of niet ${ }^{209}$ en zelfs als die overtredingen zouden zijn verjaard. ${ }^{210}$ Nochtans hoeft de fout bij een verkeersongeval dat tot letsel aanleiding geeft, niet noodzakelijk te bestaan in een inbreuk op het Verkeersreglement en kan de fout los van enige dergelijke inbreuk bestaan in een tekortkoming aan de algemene voorzichtigheidsplicht die rust op elke weggebruiker. ${ }^{21 \mathrm{II}}$ De rechter kan dan ook zonder tegenstrijdigheid veroordelen wegens het ononopzettelijk letsel-misdrijf en vrijspreken voor de overtreding van het verkeersreglement. ${ }^{212}$ Bij een vervolging wegens onopzettelijk letsel en een verkeersinbreuk kan de rechter uit de enkele vaststelling dat de verkeersinbreuk niet is bewezen, niet afleiden dat ook het onopzettelijk letsel niet is bewezen. ${ }^{213}$

\subsection{Tweede mogelijkheid: de fout bestaat in een inbreuk op de algemene zorgvuldigheidsnorm of het criterum van de normaal voorzichtige en redelijke persoon}

62. Uit de nauwgezette naleving van de wetten en reglementen volgt niet automatisch dat de beklaagde geen fout heeft begaan. ${ }^{214}$ Het naleven van de norm is geen vrijbrief. De fout kan ondanks de afwezigheid van een inbreuk op een specifieke bepaling bestaan in de niet-naleving van de algemene zorgvuldigheidsplicht.

63. Of de dader een inbreuk heeft gepleegd op die algemene zorgvuldigheidsplicht moet volgens de rechtspraak worden beoordeeld door zijn gedrag te toetsen aan de

208 Cass. 30 januari I950, AC I950, 34I; Cass. I5 mei I950, AC I950, 57I; Cass. 8 januari I95I, AC I95I, 226, JT I95I, 263, noot P. Orianne; Cass. 22 januari ig62, Pas. I962, I, 60o; Cass. I oktober I962, Pas. $1962, \mathrm{I}, \mathrm{I} 36$.

209 O.m. Cass. I7 mei I994, P.93.I526.N, AC I994, 492; Cass. I8 oktober 1995, P.05.0390.F, AC I995, 894; Cass. 20 november I996, P.96.inir.F, AC I996, I067; Cass. 7 oktober I997, P.96.o628.N, AC I997, 943 .

2Io Cass. I2 september 2007, P.07.0804.F, AC 2007, I603; Cass. 4 februari 2009, P.o8.1466.F, AC 2009, 37I; Constant, Manuel de Droit Pénal, II, p. 206-207, nr. I095.

2 II Cass. 8 februari I932, Pas. I932, 6I, B2 ${ }^{\circ}$; Cass. 9 juli I934, Pas. I934, I, 362; Cass. I5 december 1936, Pas. 1937, I, 455, I3;Cass. I5 maart I938, AC 1938, 56 ; Cass. II april I938, AC 1938, 84; Cass. I2 juli 1938, AC 1938, I75; Cass. 28 maart I939, AC 1939, I24; Cass. 25 april 1939, AC 1939, I46; Cass. 26 september I960,Pas. I96I, I, 90; Cass. 3 mei ig6r, Pas. I96I, I, 939.

2 I2 Cass. 28 januari I952, AC I952, 266; Cass. 23 juni I952, Pas. I952, I, 686; Cass. 20 september I954, AC i955, 8.

2I3 Cass. 20 februari I950, AC I950, 4I 2.

2 I4 O.m. Cass. Io maart I943, AC I943, 55; Brussel 23 december I963, RW I963-64, I879; J. Constant, Manuel de Droit Pénal. II, Les infractions, Luik: Imp. Des Invalides, s.d., p. 205, nr. I082 (hierna: Constant, Manuel de Droit Pénal, II). 
houding die een referentiepersoon in dezelfde omstandigheden zou hebben aangenomen. Die referentiepersoon wordt in de literatuur en in de rechtspraak op verschillende manieren beschreven. Het zou onder meer een normaal persoon ${ }^{215}$ of mens moeten zijn, ${ }^{216}$ de gemiddelde, redelijke en vooruitziende persoon, een normaal voorzichtig persoon bezield met gewone wilskracht en plichtsbesef, ${ }^{217}$ een normaal aandacht en voorzichtig persoon, ${ }^{218}$ een normaal bezonnen en voorzichtig man, ${ }^{219}$ een bedachtzaam, behoedzaam en opmerkzaam persoon, ${ }^{220}$ een normaal bekwaam en voorzichtig persoon, ${ }^{221}$ de goede huisvader (bonus ac diligens pater familias), de normale, voorzichtige en vooruitziende man, de verstandige dubbelganger ${ }^{222}$ of een normaal voorzichtig en redelijk persoon. ${ }^{23}$ Hierna wordt gemakkelijkheidshalve gehandeld over de normaal, voorzichtig en redelijk persoon (NVR-persoon).

64. De rechtspraak hanteert op die manier een objectief of abstract criterium: er wordt niet uitgegaan van de persoonlijke toestand van de dader op het ogenblik van de feiten, maar van een NVR-persoon.

65. Aangezien moet worden onderzocht hoe de NVR-persoon, geplaatst in dezelfde omstandigheden waarin de dader zich bevond, zich zou hebben gedragen, kan die beoordeling onmogelijk volstrekt abstract zijn. Klassiek wordt voorgehouden dat enkel rekening mag worden gehouden met de externe of uitwendige omstandigheden van plaats en tijd, ${ }^{224}$ maar de voorwaarde van het extern of uitwendig karakter van die omstandigheden is niet altijd terug te vinden in de rechtspraak van het Hof van Cassatie ${ }^{225}$ of de feitenrechters, ${ }^{226}$ die het vaak enkel heeft over 'dezelfde omstandigheden'.

66. Uit de voorwaarde dat het gedrag moet worden beoordeeld rekening houdend met dezelfde omstandigheden waarin de dader handelde of met andere woorden

215 Cass. I8 december I979, AC I979-8o, 48I; Cass. Io mei I994, P.93.II72.N, AC I994, 468; Cass. II december 2002, P.2.08I8.F, AC 2002, 273I.

2 I6 Cass. I5 december I958, AC I959, 328, RGAR I96o,nr. 6.483; Cass. I4 april I969, AC I969, 759.

217 Corr. Brugge 6 maart I937, Pas. I937, III, II.

2 I8 Cass. 24 maart I999, P.97.I357.F, AC I999, 42I.; A. Massa, O 95/2.

219 Cass. II april 1979, AC 1978-79, 967.

220 Dupont-Verstraeten, p. 257-258, nr. 443.

22 I Gent 24 december I999, T. Gez. 2000-oI, 224, noot H. Ulrichts.

222 Dupont-Verstraeten, p. 26o, nr. 448.

223 Mil. Ger. 4 juli 1996, Rev. dr. pén. I997, II5.

224 O.m. Mil. Ger. 4 juli I996, Rev. dr. pén. I997, II5; Gent I6 mei 2006, T. Gez. 2006-07, II4; Corr. Brugge 6 maart I937, Pas. I937, III, II; B. Spriet, 'Elk misdrijf - ook dat uit het bijzonder strafrecht-vereist een moreel of schuldbestanddeel', lc, 536, nr. 9; Commissie voor de herziening van het Strafwetboek, Verslag over de voornaamste grondslagen voor de hervorming, Brussel: Ministerie van Justitie, I979, p. 80-8I (hierna: Verslag commissie herziening strafwetboek); Dupont-Verstraeten, p. 260, nr. 448 .

225 Cass. I5 december 1958 , AC I959, 328; Cass. I4 april ı969, AC ı969, 759; Cass. I8 december 1979, AC I979-80, 48I; Cass. Io mei I994, P.93.II72.N, AC I994, 468; Cass. II december 2002, P.2.08I8.F, AC 2002, 273I.

226 O.m. Antwerpen I6 december 2004, T. Gez. 2006-07, 38; Corr. Dinant 3I mei 2004, T. Gez. 2005o6, 224. 
in een concreet kader, ${ }^{227}$ volgt dat de rechter die beoordeling slechts kan maken door rekening te houden met het beroep of de functie van de dader ${ }^{228}$ en zelfs met zijn opleidings- en ervaringsniveau. ${ }^{229}$ Die hoedanigheid en het ervarings-, opleidings- en specialisatieniveau zullen immers mede de in acht te nemen regels en gebruiken bepalen. ${ }^{230} \mathrm{Zo}$ is het logisch dat het referentiegedrag bij een ongeval in de nationale voetbalcompetitie dat is van een normaal voorzichtig professioneel voetbalspeler, ${ }^{231}$ dat de hoedanigheid van beroepschauffeur van zwaar vervoer ${ }^{232}$ en ook het ervaringsniveau van de betrokkene een rol kunnen spelen. ${ }^{233}$ De concrete werkomstandigheden, ${ }^{234}$ de concrete omgeving ${ }^{235}$ of de weersomstandigheden mogen bij de beoordeling worden betrokken, zodat de rechter rekening kan houden met elementen zoals de tijdsdruk, het werken in groep, de werkoverlast en andere omstandigheden eigen aan de werksituatie. Het moge duidelijk zijn dat het voor de rechter niet altijd eenvoudig is een duidelijk onderscheid te maken tussen de concrete omstandigheden van de zaak en die elementen die eigen zijn aan de beklaagde. ${ }^{236}$

67. Aldus heeft de te maken beoordeling geen puur abstract, maar wel degelijk een zeker concreet karakter ${ }^{237}$ aangezien die geval per geval en rekening houdend met de omstandigheden van de zaak moet gebeuren. ${ }^{238}$ Vandaar dat in de rechtspraak soms ook wordt gesteld dat de fout niet abstract maar concreet moet worden beoordeeld. ${ }^{239}$

227 R. Dalcq, 'Faute civile et faute pénale', Ann. Dr. Louvain,I983, 77.

228 H. Vandenberghe, M. Van Quickenborne en L. Wynant, 'Overzicht van rechtspraak. Aansprakelijkheid uit onrechtmatige daad I985-I993', TPR I995, I205, nr. 25.

229 Bijv. Brussel 27 februari I974, De Verz. I974, 637, noot R. Bogaert; R. Dalcq en G. Schamps, 'Examen de jurisprudence (I987 à 1993). La responsabilité délictuelle et quasi délictuelle', RCJB I995, 540, nr. 9 .

230 A. Andries, 'Aspects particuliers du défaut de prévoyance punissable dans les activités militaires', Rev. dr. pén. 1994, 344 ; C. Hennau-Hublet, 'L'activité médicale et les délits d'atteinte à la vie, l'integrité physique et la santé des personnes', Rev. dr. pén. I986, 590.

23 I M. Adams, 'Is risico-aanvaarding een zelfstandig juridisch concept?', (noot onder Antwerpen 25 juni r993), RW I993-94, 305, nr. 4.

232 Corr. Charleroi 23 mei I977, RGAR I978, nr. 9.9I4.

233 Corr. Brugge 6 maart I937, Pas. I937, III, II.

234 Luik I9 maart I959, Rev. dr. pén. I958-59, 805.

235 Cass. I5 december 1958 , AC 1959, 328.

236 R. Dalcq, 'Examen de jurisprudence (I968 à 1972). La responsabilité délictuelle et quasi délictuelle', RCJB I973, 632, nr. 7; R. Dalcq, 'Examen de jurisprudence (I973 à I979). La responsabilité délictuelle et quasi délictuelle', RCJB I980, 36r, nr. 5; H. Vandenberghe, M. Van Quickenborne en P. Hamelink, 'Overzicht van rechtspraak. Aansprakelijkheid uit onrechtmatige daad I964-I978', TPR I980, II65-II66, nr. I8.

237 R. Dalcq, Noot onder Cass. I5 december I958, RGAR I96o, nr. 6.483/2R, nr. 3; B. Spriet, 'Elk misdrijf - ook dat uit het bijzonder strafrecht - vereist een moreel of schuldbestanddeel', lc, 536 , nr. 9 .

238 Cass. II april 1979, AC $1978-79,967$.

239 Bijv. Corr. Luik 23 april 2008, De Verz. 2009, 174. 
68. Ook een ambtenaar ${ }^{240}$ of een politiek mandataris ${ }^{241}$ of een sportman- of vrouw ${ }^{242}$ dient de algemene zorgvuldigheidsplicht na te leven. Indien zijn gedrag afwijkt van wat van een NVR-ambtenaar of -politicus of -sportman of -sportvrouw in die omstandigheden kan worden verwacht, volgt een schuldigverklaring aan het onopzettelijk letsel-misdrijf.

69. Te benadrukken is dat de referentiepersoon geen supermens is, maar een normaal mens met zijn gebreken en beperkingen. ${ }^{243}$ De menselijke limieten vormen immers de grenzen van het strafrecht. De toetsing moet gebeuren aan de hand van menselijke criteria ${ }^{244}$ en rekening houdend met de maatschappelijke gewoonten en de stand van de industrie en de wetenschap ${ }^{245}$ op het ogenblik van het schadeverwekkende feit en dus niet op het ogenblik van de rechterlijke beslissing. ${ }^{2{ }^{26}} \mathrm{De}$ rechter mag niet uit het oog verliezen dat ook een NVR-persoon niet onfeilbaar is en schade kan veroorzaken. Zo kan bijvoorbeeld een verantwoorde en correct uitgevoerde medische behandeling schadelijke neveneffecten hebben, zonder dat onzorgvuldig werd gehandeld. ${ }^{247}$

70. Er mag geen onbeperkte zorgvuldigheidsplichtworden opgelegd. Aan de betrokkene kan niet worden verweten dat hij een bepaalde handeling niet heeft gesteld, indien de wenselijkheid van die handeling enkel is gebleken als gevolg van het zich voordoen van het onopzettelijk letsel. ${ }^{24}{ }^{8}$ Het niet-stellen van een voorzichtigheidsmaatregel die op het ogenblik van de feiten niet gebruikelijk was, maar waarvan achteraf blijkt dat deze het letsel had kunnen voorkomen, is niet foutief. Het foutief karakter van een (niet-)handelen mag niet worden afgeleid uit het resultaat van dat (niet-)handelen, maar wel uit het al dan niet afwijken van wat had moeten worden gedaan. ${ }^{249}$

7I. De zorgvuldigheidsnorm is een vaag en relatief begrip, die in ruime mate wisselende maatschappelijke waardeoordelen weerspiegelt en waarbij de persoonlijke visie van de rechter over wat aanvaardbaar is een grote rol speelt. ${ }^{25}$

240 O.m. Cass. 29 november I93I, Pas. I93I, I, 29I; Cass. I8 december I979, AC I979-80, 48I.

24I O.m. Luik 26 maart I987, Verkeersr. I988, 78, noot F. Glansdorff.

242 R. Dalcq, 'Examen de jurisprudence (I973 à I979)...' l.c., 363, nr. 9.

243 Corr. Leuven 20 mei 2003, T. Gez. 2004-05, 228; R. Dalcq, Noot onder Cass. I5 december I958, RGAR i960, nr. 6.483/IV, nr. 2.

244 Brussel i7 oktober i969, RW i969-70, 474.

245 Corr. Charleroi 23 mei I977, RGAR I978, nr. 9.9I4; Yves, noot onder Brussel 6 juli i927, Rev. dr. pén. I927, 1076.

246 Antwerpen 22 november I99o, Vl. T. Gez. I993-94, I48.

247 S. Van Overbeke, 'De arts in de beklaagdenbank. ...' l.c., 926.

248 J. Du Jardin, Concl. bij Cass. 23 januari I99I, Rev. dr. pén. I992, 315; Gesché, Concl. bij Cass. 23 november I93I, Pas. I93I, I, 29I; C. Hennau-Hublet, 'L'activité médicale et les délits d'atteinte à la vie ...', l.c., 580; C. Hennau-Hublet, 'L'action civile fondée sur le délit de coups et blessures par imprudence', l.c., II.938/3; C. Hennau-Hublet, 'La responsabilité pénale pour coups et bléssures involontaires en raison d'un comportement d'omission', l.c., 330.

249 J. Du Jardin, Concl. bij Cass. 23 januari I99I, Rev. dr. pén. 1992, 315.

$250 \mathrm{H}$. Bocken en I. Boone, Inleiding tot het schadevergoedingsrecht, Brugge: Die Keure 20II, p. IOI. 


\section{Io. De vereiste van het voorzienbaar en vermijdbaar schadelijk gevolg}

72. Er kan slechts sprake zijn van een fout indien het beweerd foutief handelen of het beweerd foutief verzuim heeft geleid tot een voorzienbaar en vermijdbaar schadelijk gevolg. ${ }^{251}$ Er kan geen schuld zijn aan het onvoorzienbare en er kan geen schuld bestaan in het niet kunnen vermijden van het onvermijdbare..$^{252}$

73. Opdat een gedraging een onvoorzichtigheid of een gebrek aan voorzorg zou zijn in de zin van de artikelen $4 \mathrm{I} 8$ en 420 Sw. moet die niet van dien aard zijn dat die noodzakelijk schade zal veroorzaken. ${ }^{253}$ Wel is vereist dat mogelijkheid van schade kon worden voorzien, ${ }^{254}$ zonder dat het daarbij voor strafbaarheid van belang is wie precies de schade zou lijden. ${ }^{255}$ Niet de omvang van de schade, maar het bestaan ervan moet voorzienbaar zijn. ${ }^{25}$ Indien de dader de schade niet kon voorzien, is er geen misdrijf: de voorzienbaarheid is een essentieel element. ${ }^{257}$ Het gebrek aan voorzichtigheid of voorzorg kan bestaan in het geen rekening houden met een mogelijkheid, als die mogelijkheid kon worden voorzien of had moeten voorzien worden..$^{25}$

74. Er wordt niet uitgegaan van een feitelijke effectieve voorzienbaarheid, maar wel van een redelijke voorzienbaarheid, ${ }^{259}$ die te beoordelen is in het licht van het naar de omstandigheden geconcretiseerde criterium van de NVR-persoon. ${ }^{260} \mathrm{Bij}$ de beoordeling moet rekening worden gehouden met de middelen waarover de betrokken dader beschikte of kon beschikken. ${ }^{26 r}$

75. De niet-naleving van een wettelijke of reglementaire bepaling levert automatisch een gebrek aan voorzichtigheid of voorzorg op, zonder dat moet worden nagegaan of de schade voorzienbaar was. ${ }^{262}$ Sommige auteurs verdedigen nochtans dat aan de voorwaarde van de voorzienbaarheid van de schade ook in een dergelijk geval moet zijn voldaan. Indien de overtreder van de reglementaire bepaling niet kon voorzien

25I Luik I3 maart I935, RGAR I935, nr. I.796; Mil. Ger. 4 juli I996, Rev. dr. pén. I997, II5; De Nauw, Inleiding tot het Algemeen Strafrecht 2010, p. 47, nr. 86.

252 Dupont-Verstraeten, p. 259, nr. 447.

253 O.m. ass. I2 november I95I, AC I952, II8; Cass. I6 juni ı969, AC ı969, I026; Cass. I3 juni I978, AC I978, I202.

254 Cass. I2 november I95I, AC I952, II8; Cass. I3 juni I978, AC I978, I202; Luik i9 maart I959, Rev. dr. pén. $1958-59,805$.

255 O.m. Cass. 8 augustus I990, AC I989-90, I42I.

256 Corr. Luik 27 november 1963 , JT ig64, I30.

257 Cass. I4 januari 1974, AC 1974, 532; R. Dalcq, Noot onder Cass. I5 december I958, RGAR I960, nr. 6.483/2R, nr. 4; J. Du Jardin, Concl. bij Cass. 23 januari I99I, Rev. dr. pén. I992, 3I5.

258 O.m. Cass. 25 maart I964, Pas. I964, I, 73I; Cass. 31 oktober I966, AC I967, 299; Cass. 23 oktober 1967, AC I968, 282; Cass. Io mei 1994, P.93.II72.N, AC 1994, 486; Cass. II december 2002, P.2.08I8.F, AC 2002, 273I; Bergen 8 februari I985, JT I985, 593.

259 Cass. I7 januari I955, AC I955, 375; Cass. I9 april I978, AC I978, 949; H. Vandenberghe en M. Van Quickenborne, m.m.v. K. Geelen en S. De Coster, 'Overzicht van rechtspraak. Aansprakelijkheid uit onrechtmatige daad I979-I984', TPR I987, I290, nr. I6.

$260 \mathrm{H}$. Vandenberghe, 'Overzicht van rechtspraak. Aansprakelijkheid uit onrechtmatige daad 20002008', TPR 2010, I855, nr. 38.

26I Mil. Ger. 4 juli I996, Rev. dr. pén. I997, II5.

262 Bijv. Corr. Leuven 20 mei 2003, T. Gez. 2004-05, 228. 
dat die overtreding schade had kunnen veroorzaken, kan hij enkel schuldig zijn aan de overtreding van de bepaling zo die strafrechtelijk sanctioneerbaar is, maar niet aan onopzettelijk letsel. ${ }^{263}$

\section{II. De lichtste fout volstaat}

76. Het Hof van Cassatie ${ }^{264}$ en de meerderheid van de feitenrechters ${ }^{265}$ nemen op basis van de parlementaire voorbereiding van het Strafwetboek aan dat de lichtste fout (culpa levissima) of dus de minste onachtzaamheid ${ }^{266}$ voor strafrechtelijke verantwoordelijkheid volstaat. ${ }^{267}$ Die leer is in overeenstemming met de klassieke doctrine. ${ }^{268}$ Die regel geldt evengoed als de beklaagden politieke mandatarissen zijn, ${ }^{269}$ ook al werd bij de vervolging van een schepen wegens een onopzettelijk letsel ingevolge een beweerde gebrekkige weginfrastructuur uitzonderlijk geoordeeld dat een zware fout noodzakelijk zou zijn. ${ }^{270}$

77. Geïnspireerd door opvattingen in de rechtsleer ${ }^{271}$ werd geoordeeld dat de lichtste fout (culpa levissima) geen relevant criterium is, maar dat de beklaagde een lichte fout (culpa levis) moet hebben begaan. ${ }^{272}$ Dat lijkt eerder een spelen met woorden omdat

263 Colette-Basecqz en Blaise, Manuel de droit pénal général, p. 265 en noot (650); R. Dalcq, 'La prévisibilité du dommage est-elle une condition nécessaire de la faute', in: Hommage à Jacques Heenen, Brussel: Bruylant I994, p. 83 e.v.; C. Hennau-Hublet, 'L'activité médicale et les délits d'atteinte à la vie ..., l.c., p. 589 en noot (59); Hennau-Verhaegen, Droit pénal général 2003, p. 357-358, nr. 4I3; C. Rokofyllos, Le concept de lésion et la répression de la délinquance par imprudence. Essai de critique, Parijs: LGDJ I967, p. 79, nr. 8o; G. Schamps, 'Le relâchement des liens entre les responsabilité pénale et civile. La mise en danger, distinct du principe de precaution, in: Y. Poullet en H. Vuye (red.), Liber Amicorum Jean Du Jardin, Deurne: Kluwer 200I, p. 4I6.

264 Cass. 26 mei 1952, AC I952, 54I; Cass. II oktober I97I, AC 1972, I6I; Cass. 8 november I976, AC I977, 274; Cass. 27 september I985, AC I985-86, 96, RW I985-86, I388, noot; Cass. I5 december I992, AC I99I-92, I437; Cass. I2 september 2007, P.07.0804.F, AC 2007, I603.

265 O.m. Luik 27 december I879, Pas. I88o, II, I4I; Brussel 6 juli I927, Rev. dr. pén. I927, I076, noot Yves; Gent 29 januari I993, TGR I993, I44; Gent 3 juni I997, AJT 1997-98, I09, noot L.A; Antwerpen 22 november 1990, Vl. T. Gez. 1993-94, I48; Antwerpen I6 december 2004, T. Gez. 2006-07, 38; Corr. Verviers 7 juni I877, Pas. I877, III, 254; Corr. Brugge 6 maart 1937, Pas. I937, III, II; Jeugdrb. Dinant 25 april I973, Pas. I974, III, 2; Corr. Neufchâteau 26 mei I983, Rev. dr. pén. I983, 809; Corr. Dendermonde 7 maart 200I, De Juristenkrant 200I/28, 4; Corr. Brussel 20 januari 2004, Soc. Kron. 2005, 455; Corr. Dinant 3I mei 2004, T. Gez. 2005-06, 224; Corr. Nijvel I3 september 2007, RGAR 2008, nr. I4.376; Corr. Luik 23 april 2008, De Verz. 2009, I74; Corr. Brussel 4 september 2008, JLMB 20I0, 665, noot N. Bernard; Corr. Neufchâteau 6 oktober 20I0, VAV 20II, 4I7; Pol. Leuze I3 januari I96I, De Verz. I963, 592; Pol. Mechelen 6 december I999, TAVW $2000,70$.

266 Luik i8 maart I896, Pas. I896, II, 264.

267 De Nauw, Inleiding tot het Algemeen Strafrecht 2010, p. 47, nr. 86; De Nauw, Bijzonder strafrecht 2010, p. 216, nr. 268.

268 Nypels-Servais, Le code pénal belge interprété, III, p. II8, nr. 7.

269 Luik 26 maart I987, Verkeersr. I988, 78, noot F. Glansdorff.

270 Luik 2 februari ig89, RGAR I990, nr. II.700, noot F. Glansdorff.

27 I O.m. H. Vandenberghe, M. Van Quickenborne en P. Hamelink, 'Overzicht van rechtspraak. Aansprakelijkheid uit onrechtmatige daad I964-I978', TPR I980, II59-II6I, nr. I3-I4; H. Vandenberghe en M. Van Quickenborne, m.m.v. K. Geelen en S. De Coster, 'Overzicht van rechtspraak. Aansprakelijkheid uit onrechtmatige daad I979-I984', TPR I987, I3I2, nr. 27; H. Vandenberghe, M. Van Quickenborne en L. Wynant, 'Overzicht van rechtspraak. Aansprakelijkheid uit onrechtmatige daad I985-I993', TPR I995, I209-I210, nr. 27.

272 Bijv. Corr. Leuven 20 mei 2003, T. Gez. 2004-05, 228. 
het uitgangspunt is dat elke afwijking van het gedrag van een NVR-persoon foutief is, met dien verstande dat niet uit het oog mag worden verloren dat die NVR-persoon een normaal en dus geen supermens is. Bovendien is bij de overtreding van een specifieke rechtsnorm de toetsing aan het zorgvuldigheidscriterium niet aan de orde.

78. De regel dat ook de lichtste fout volstaat, belet niet dat de rechter soms vaststelt dat de beklaagde een ernstig te nemen of een zware of zeer zware fout heeft begaan. ${ }^{273}$ Vermeldingen dat de beklaagde een groot gebrek aan voorzorg en voorzichtigheid heeft betoond, dat de door hem gepleegde fout bijzonder zwaar is en dat de inbreuken op de onopzettelijk letsel-misdrijven zeer zwaarwichtig zijn ${ }^{274}$ worden opgenomen om een gestrengheid bij de straftoemeting te verantwoorden. Soms wordt een gradatie in de vastgestelde fouten gemaakt om het verschil in straftoemeting tussen de beklaagden te verantwoorden. ${ }^{275}$ In het relatief weinig ernstig karakter van de vastgestelde fout kan een reden worden gezien om verzachtende omstandigheden aan te nemen..$^{276}$ De omstandigheid dat de feitenrechter in hoofde van de dader een zware, met het opzet verwante, fout vaststelt, maakt een veroordeling wegens de onopzettelijk letsel-misdrijven in elk geval niet onwettig. ${ }^{277}$

\subsection{Het verband tussen de fout en het letsel}

8o. Het is niet de bedoeling de problematiek van de vereiste van het oorzakelijk verband tussen het gebrek aan voorzichtigheid of voorzorg en de dood of de slagen of verwondingen aan een ander te bespreken. Enkel twee punten zijn aan te stippen.

8I. Het is niet vereist dat de fout van de beklaagde de enige en exclusieve oorzaak is van het letsel. ${ }^{278}$ De rechter kan wegens onopzettelijk letsel veroordelen indien hij vaststelt dat de fout van de dader rechtstreeks verband houdt met dat letsel en de door de dader aan het slachtoffer of aan derden toegeschreven fouten de door hem begane fout niet uitsluiten. ${ }^{279}$ De fout van een medebeklaagde, ${ }^{280}$ van een derde ${ }^{281}$ of van het slachtoffer ${ }^{282}$ kan op zichzelf het oorzakelijk verband tussen enerzijds de

273 Bijv. Mil. Ger. 26 maart I98I, RGAR I982, nr. I0.534; Corr. Gent 8 juli I953, JT i954, 67; Corr. Leuven 20 mei 2003, T. Gez. 2004-05, 228.

274 Bergen 8 februari I985, JT I985, 593; Pol. Antwerpen 7 juni 2000, Verkeersrecht 200I, 90.

275 Luik 3i januari I856, Pas. I856, II, I05; Gent 26 februari I873, Pas. I873, II, I7I); Corr. Brussel 20 januari 2004, Soc. Kron. 2005, 455.

276 Luik 25 maart I94I, De Verz. I942, 70I.

277 Cass. 6 juli 1925, Pas. I925, I, 329.

278 O.m. Cass. 4 juli I955, AC I955, 904; Cass. 20 mei 1957, AC 1957, 795; Cass. 29 oktober I962, RW I962-63, I886; Cass. I4 mei 2008, P.o7.III2.F, AC 2008, II82; Brussel I3 maart I970, RW I969-70, I794; Luik 6 november 1990, RGAR I993, nr. I2.I84; Mil. Ger. 4 juli 1996, Rev. dr. pén. I997, II5; R. Declercq, 'Enkele problemen i.v.m. de toepassing van de artikelen 4I8, 4I9 en 420 van het Strafwetboek', l.c., I95.

279 O.m. Cass. 3 mei ig6I, Pas. I96I, I, 94I.

280 Cass. 2 juli i95I, AC I95I, 65I.

28 I O.m. Cass. 4 juni Ig62, Pas. I962, I, II23; Cass. I4 mei 2008, P.o7.III2.F, AC 2008, II82; Luik 29 mei I94I, RGAR I94I, nr. 3.527.

282 Cass. 24 februari I902, Pas. I902, I, I6I, concl. Van Schoor; Cass. 2 april I95I, Pas. I95I, I, 504; Cass. 8 februari ig62, Pas. I962, I, 539; Cass. 22 februari I938, AC I938, 32; Cass. 23 juli I94I, AC 
onvoorzichtigheid van de dader en anderzijds de schade niet wegnemen. Ze kan wel aanleiding geven tot een verdeling van aansprakelijkheid. ${ }^{283}$

82. Het oorzakelijk verband tussen de fout en het letsel moet zeker zijn. Dat dit oorzakelijk verband mogelijk of zelfs waarschijnlijk is, volstaat niet voor een schuldigverklaring aan een onopzettelijk letsel-misdrijf. ${ }^{284}$ De erkenning van het verlies van een kans als vergoedbare schade kan er niet toe leiden dat op strafrechtelijk gebied de vereiste van het bestaan van een zeker oorzakelijk verband wordt ter zijde geschoven. ${ }^{285}$

\subsection{De afstand in de tijd en in de ruimte tussen de fout en het lichamelijk letsel}

83. De artikelen $4 \mathrm{I} 8$ en 420 Sw. vereisen niet dat de fout en de doding of de slagen of verwondingen op hetzelfde ogenblik plaatsgrijpen. De fout kan bestaan in een voorafgaande beslissing. ${ }^{286}$ Voor strafbaarheid is niet vereist dat de dader aanwezig was op het ogenblik van het onopzettelijk letsel. ${ }^{287}$ Het gebrek aan voorzichtigheid of voorzorg kan gebeuren op een andere plaats dan het ongeval waartoe de fout aanleiding geeft, ${ }^{288}$ zodat het misdrijf kan hebben plaatsgegrepen op verschillende plaatsen. Het is dus denkbaar dat het gebrek aan voorzichtigheid of voorzorg te situeren is in België, terwijl het ongeval in het buitenland plaatsvindt. ${ }^{289}$

\section{I4. Andere aspecten van strafrecht: schulduitsluiting, geen strafbare poging, geen strafbare deelneming}

84. De enkele omstandigheid dat de beklaagde de voor het onopzettelijk letselmisdrijf vereiste fout heeft begaan, leidt niet automatisch tot zijn schuldigverklaring. Er kan immers een grond van schulduitsluiting voorhanden zijn, zoals overmacht of onoverwinnelijke dwaling. ${ }^{29 \circ}$ Onoverwinnelijke dwaling sluit elke strafrechtelijke fout uit. ${ }^{291}$ Indien de beklaagde die schulduitsluitingsgrond enigszins geloofwaardig maakt, is het aan de vervolgende partij om het tegendeel te bewijzen.

I94I, I78; Cass. II februari 2009, AC 2009, 482; Luik I2 februari I869, Pas. I869, II, 390; Brussel 30 mei I917, Pas. I9I9, II, 32; Corr. Brugge 6 maart I937, Pas. I937, III, II; Krijgsr. Vlaanderen 28 februari I931, Rev. dr. pén. I931, 498, noot C.C.

283 Luik 22 februari I869, Pas. I869, II, 390.

284 Cass. 23 september 1974, AC $1975,97$.

285 Bijv. Cass. I7 september 2003, JT 2004, 95, noot; KI Antwerpen I2 november 2009, T. Gez. 20II-I2, 387, noot QDR; Cass. 27 januari 2009, RW 20I0-II, 754, noot; Rk. Ieper 27 januari 2009, RW 2010II, 754, noot; Corr. Tongeren ig maart 2009, Limb. Rechtsl. 20II, I67; R. Dalcq, 'Faute civile et faute pénale ..., l.c., 75-76; A. Masset, 'La perte d'une chance de survie retenue comme élément de l'homicide involontaire' RGAR 1999,nr. I3.153; S. Van Overbeke, 'De arts in de beklaagdenbank. ...' l.c., 928-933.

286 Cass. I6 november I999, P.97.0359.N, AC I999, I442.

287 Cass. 29 januari 1923 , Pas. I923, I, I73.

288 Cass. I6 november I999, P.97.0359.N, AC I999, I442.

289 Cass. 8 mei igir, Pas. I9II, I, 244.

290 Spreutels, Roggen en Roger France, Droit pénal des affaires, 945; S. Van Overbeke, 'De arts in de beklaagdenbank. ...' l.c., 925 .

29I Luik ig maart I959, Rev. dr. pén. 1958-59, 805. 
85. Het is niet mogelijk om te pogen het wanbedrijf van onopzettelijk letsel te plegen. De strafbare poging veronderstelt volgens artikel ${ }_{51}$ Sw. immers het voornemen om een misdaad of wanbedrijf te plegen, wat een opzet veronderstelt.

86. De bepalingen van het Strafwetboek inzake strafbare deelneming zijn niet toepasselijk op de onopzettelijke misdrijven en bijgevolg ook niet op de onopzettelijk letsel-misdrijven. ${ }^{292}$ Die regel sluit nochtans niet uit dat meerdere personen als dader voor een onopzettelijk letsel-misdrijf verantwoordelijk zijn, indien zij allen een fout hebben begaan. ${ }^{293}$ Deze bepalingen bestraffen niet alleen hij die rechtstreeks letsel veroorzaakt, maar elkeen die daartoe heeft bijgedragen door een al dan niet gemeenschappelijke fout. ${ }^{294} \mathrm{Al}$ die personen kunnen op grond van artikel $50 \mathrm{Sw}$. hoofdelijk worden veroordeeld tot schadevergoeding. ${ }^{295}$ Zo kunnen de verschillende beoefenaars van de geneeskunde die elk een onachtzaamheid hebben begaan die in oorzakelijk verband staat met de doding of het letsel worden veroordeeld.

87. Het gegeven dat de beslissingsbevoegdheid bij een collegiaal orgaan ligt, sluit niet uit om in hoofde van de leden ervan een - individueel - gebrek aan voorzichtigheid of voorzorg vast te stellen. De in hoofde van het college van burgemeester en schepenen vastgestelde onachtzaamheid door niet op te treden met betrekking tot een onveilig aangelegde verkeersdrempel met een dodelijk ongeval tot gevolg, is toerekenbaar aan elk lid van het college, indien die beslissing unaniem en zonder enig voorbehoud werd genomen. ${ }^{296}$ Alle leden van een schepencollege werden schuldig verklaard aan onopzettelijk letsel omdat zij met betrekking tot het gemeentelijk zwembad niet de gepaste maatregelen hadden genomen met als gevolg de lozing van chloorgas en het onwel worden en de opname in het ziekenhuis voor verzorging van $6_{3}$ bezoekers. In hoofde van elk lid van het college werd een individueel gebrek aan voorzichtigheid of voorzorg vastgesteld. ${ }^{297}$ De burgemeester en schepen van openbare werken die niet adequaat hadden gereageerd op een onveilige toestand van een weg met een dodelijk verkeersongeval tot gevolg, werden schuldig bevonden aan onopzettelijke doding. ${ }^{298}$

292 Cass. I6 oktober I972, AC I973, I65; Cass. I5 oktober I986, AC I986-87, 200, RW I987-88, 2I, noot M. De Swaef; Luik 9 november 1957, JL 1957-58, 97.

293 M. De Swaef, 'Over daders en mededaders', (noot onder Cass. I5 oktober I986), RW I987-88, 22, nr. 3 .

294 Cass. 3 maart I924, Pas. I924, I, 229; Cass. 29 oktober I962, RW I962-63, I886; Cass. I6 oktober I972, AC I973, I65; Corr. Neufchâteau 26 mei ig83, Rev. dr. pén. I983, 809.

295 R. Declercq, 'Enkele problemen i.v.m. de toepassing van de artikelen 4I8, 4I9 en 420 van het Strafwetboek', l.c., I97.

296 Cass. 3 maart I999, P.97.I384.F, AC I999, 293, concl. J. Spreutels, R. Cass. I999, 333, noot L. Veny, Rev. dr. commun. 200I, I34, noot J. Van Bol.

297 Corr. Dendermonde 7 maart 200I, De Juristenkrant 200I/28, 4.

298 Luik 26 maart I987, Verkeersr. I988, 78, noot F. Glansdorff. 


\section{I5. Aspecten van strafprocesrecht: geen verwittingsplicht, bewijslast, beoordeling door de feitenrechter en motiveringsplicht}

88. Bij een vervolging wegens onopzettelijk letsel-misdrijven beoordeelt de strafrechter op basis van de hem voorgelegde en aan de tegenspraak van partijen onderworpen dossiergegevens waarin het gebrek aan voorzichtigheid of voorzorg bestaat en moet hij daartoe alle fouten die een dergelijk gebrek uitmaken in aanmerking nemen. De rechter op verzet of in hoger beroep kan voor de schuldigverklaring aan een ander gebrek aan voorzichtigheid of voorzorg in aanmerking nemen dan dat welke de rechter op verstek of de eerste rechter heeft aangenomen. ${ }^{299}$

89. Het is niet vereist dat de dagvaarding de tekortkoming aan de voorzichtigheid of voorzorg van de beklaagde nader preciseert. ${ }^{300}$ Een precisering zou misleidend kunnen zijn: de verdediging zou aldus geneigd kunnen zijn het verweer te beperken tot die wel bepaalde fout, terwijl de rechter nadien schuldig zou kunnen verklaren op grond van een andere fout. Bovendien lijkt het niet aannemelijk dat het Openbaar Ministerie zo de beoordelingsvrijheid van de rechter zou kunnen inperken. ${ }^{\text {or }}$ Ook de strafrechter is er niet toe gehouden om bij de behandeling van de zaak aan een beklaagde mee te delen welke tekortkomingen aan de voorzichtigheid of de voorzorg tegen de beklaagde zouden kunnen worden weerhouden. ${ }^{302}$ De beklaagde dient zich bijgevolg te verdedigen omtrent alle vormen van gebrek aan voorzichtigheid of voorzorg, die oorzaak van het letsel kunnen zijn geweest. ${ }^{303}$ Hij kan zijn verweer dus niet beperken tot de fout die de burgerlijke partij in een appèlconclusie heeft aangevoerd. ${ }^{304}$ De rechter die in zijn vonnis het gebrek aan voorzichtigheid of voorzorg preciseert, heromschrijft de tenlastlegging niet, zodat hij de beklaagde niet voorafgaandelijk moet verwittigen. ${ }^{305}$ Dat is ook zo als die precisering bestaat in de vaststelling dat het gebrek aan voorzichtigheid of voorzorg bestaat in een niet vervolgd misdrijf. ${ }^{306}$

90. Dit alles houdt volgens de Belgische rechtspraak geen schending in van artikel II $38,2^{\circ}$, Ger. W., van het recht van verdediging of van het recht op een eerlijk proces zoals gewaarborgd door artikel 6.I en 6.3.a EVRM en door artikel I4.I en I4.3.a en b IVBPR. Artikel 6.3.a EVRM vereist niet dat de feitelijke gegevens waarop de vervolging is gegrond in de tenlastlegging zouden worden geëxpliciteerd..$^{307}$ De beklaagde

299 Cass. I6 oktober I99I, AC I99I-92, I55.

300 De Nauw, Bijzonder strafrecht 2010, p. 227, nr. 279.

$30 \mathrm{I}$ R. Declercq, 'Enkele problemen i.v.m. de toepassing van de artikelen 4I8, 4I9 en 420 van het Strafwetboek', l.c., 2 I9.

302 Cass. 2I december I953, AC I954, 28I; Cass. 20 september I954, AC I955, 8; Cass. I6 oktober I99I, AC I99I-92, I55; Gent 25 april I978, RW I979-80, I256.

303 Cass. 17 mei I994, P.93.I526.N, AC I994, 492; Cass. 20 november 1996, P.96.IIII.F, AC I996, Io67; Cass. 7 oktober 1997, P.96.o628.N, AC 1997, 943.

304 Cass. 3I mei 2000, P.00.0235.F, AC 2000, I017.

305 Cass. 4 november 1997, P.95.0907.N, AC 1997, 107I.

306 Cass. 5 november 1997, P.97.089o.F, AC 1998, 1078.

307 Cass. 4 november I997, P.95.0907.N, AC I997, I07I. 
is op basis van de inleidende akte, de stukken van het dossier, het onderzoek ter terechtzitting en het debat dat daarop volgt voldoende ingelicht over wat hem ten laste wordt gelegd en kan zo ten volle zijn recht van verdediging uitoefenen..$^{308}$ Het Hof van Cassatie heeft die stelling in een recent arrest met betrekking tot een onachtzaamheidsmisdrijf uit het economisch strafrecht bevestigd. ${ }^{309}$

9I. De rechtsleer is er niet van overtuigd dat een omschrijving van de tenlastlegging in algemene bewoordingen verenigbaar is met artikel 6.3.a EVRM. ${ }^{\text {I0 }}$ Volgens die bepaling heeft de beklaagde het recht om onverwijld en in bijzonderheden op de hoogte te worden gesteld van de aard en de reden van de tegen hem ingebrachte beschuldiging. Is de verplichting voor de beklaagde om via een onderzoek van de dossiergegevens op zoek te gaan naar een bepaald constitutief bestanddeel van het ten laste gelegde misdrijf niet strijdig met dit recht? ${ }^{3 \text { I }}$

92. De vervolgende partij moet de fout bewijzen..$^{312}$ Het loutere bewijs van schade ${ }^{313}$ en meer bepaald van letsels, volstaat evident niet. ${ }^{34}$ Aan de beklaagde mag geen bewijslast worden opgelegd. Een schuldigverklaring aan een onopzettelijk letselmisdrijf die steunt op de overweging dat de beklaagde niet bewijst dat hij enige inspanning heeft gedaan om de onveilige verkeerssituatie te (laten) signaleren, zodat het vastgestelde verzuim hem persoonlijk in de uitoefening van zijn ambt dient te worden toegerekend, wordt vernietigd. ${ }^{315}$

93. De feitenrechter oordeelt onaantastbaar in feite of er sprake is van een onachtzaamheid. ${ }^{316}$ De cassatierechter kan wel nagaan of de feitenrechter op basis van zijn vaststellingen wettig kon beslissen tot die onachtzaamheid..$^{37}$

308 Cass. 20 november I996, P.96.IIII.F, AC I996, I067; Cass. 7 oktober I997, P.96.o628.N, AC I997, 943; Cass. 5 november 1997, P.97.0890.F, AC I998, I078; Cass. 3I mei 2000, P.00.0235.F, AC 2000, I0I7; Gent 25 april 1978, RW I979-80, I256.

309 Cass. 29 november 20II, P.Io.I766.N, ro I2I, I28 en I29.

3IO De Nauw, Bijzonder strafrecht 2010, p. 227, nr. 279.

3 II R. Verstraeten, Handboek strafuordering, Antwerpen: Maklu 2007, p. 799, nr. I66I.

3 I2 Gent 28 december I867, Pas. I888, II, 37; Brussel 3 juli I945, Pas. I945, II, 5I; R. Declercq, 'Enkele problemen i.v.m. de toepassing van de artikelen 4I8, 4I9 en 420 van het Strafwetboek', l.c., I94.

313 Cass. 3 mei 1958, Pas. 1958, I, 972; Mil. Ger. 4 juli 1996, Rev. dr. pén. I997, II5.

3 I4 Gent 24 december I999, T. Gez. 2000-oI, 224, noot H. Ulrichts; Corr. Leuven 3I maart 2009, T. Strafr. 2009, 323, noot.

3 I5 Cass. 27 november 2007, P.07.II3I.N, AC 2007, 2288.

$3 \mathrm{I} 6$ Cass. 27 oktober I89o, Pas. I89o, I, 292; Cass. 27 november I899, Pas. I900, I, 46; Cass. 30 juni I924, Pas. I924, I, 436; Cass. 8 januari I95I, AC I95I, 226, JT I95I, 263, noot P. Orianne; Cass. I7 januari 1955, AC I955, 375; Cass. I oktober 1962, Pas. I962, I, I36; Cass. 29 oktober I962, RW I962-63, I886; Cass. I6 juni i969, AC 1969, I026; Cass. 8 november 1976, AC I977, 274; Cass. II april I979, AC I978-79, 967; Gent 29 januari I993, TGR I993, I44; Mil. Ger. 4 juli I996, Rev. dr. pén. I997, II5.

317 Bijv. Cass. 7 maart I955,Pas. I955, I, 746; R. Dalcq, 'Examen de jurisprudence (I980 à I986). La responsabilité délictuelle et quasi délictuelle', RCJB I987, 607, nr. 3; R. Dalcq en G. Schamps, 'Examen de jurisprudence (1987 à 1993). La responsabilité délictuelle et quasi délictuelle', RCJB I995, 549, nr. I7; H. Vandenberghe, 'Overzicht van rechtspraak. Aansprakelijkheid uit onrechtmatige daad 2000-2008', TPR 2010, I763-1765, nr. Io. 
94. De rechter moet ondubbelzinnig de fout vaststellen en aangeven waarin ze bestaat. Anders belet hij de cassatierechter zijn wettigheidstoezicht uit te oefenen..$^{3^{18}}$ De rechter verantwoordt een schuldigverklaring wegens onopzettelijk letsel niet naar recht indien hij de fout niet omschrijft. Indien hij een fout vaststelt, moet hij niet de redenen van die fout vermelden. ${ }^{319}$ Het oordeel dat als een fout moet worden aangemerkt het feit dat de bestuurder van de baan is afgeraakt en zijn rijgedrag zijn doel niet heeft bereikt, indien de dader voor het ongeval geen andere oorzaak dan zijn rijgedrag aantoont, voldoet niet aan de vereiste. ${ }^{320}$ De rechtspraak dat bij afwezigheid van conclusies de rechter zich ertoe kan beperken het feit bewezen te verklaren in de bewoordingen van de artikelen 4I8-420 Sw. ${ }^{32 \mathrm{I}} \mathrm{kan}$ ook niet worden bijgetreden, temeer daar het Hof van Cassatie sinds het arrest van 8 juni 201 I eist dat de rechter ook bij ontstentenis van conclusie de voornaamste redenen vermeldt ter verantwoording van zijn beslissing over de strafvordering, ook al mag dit beknopt zijn. ${ }^{322}$ Evident moet de rechter een bij regelmatige conclusie aangevoerd verweer beantwoorden omtrent (het ontbreken van) de fout. ${ }^{323}$

\section{I6. Conclusie: de onder- en bovengrens van onachtzaamheid}

95. Uit wat voorafgaat blijkt dat de ondergrens voor de onachtzaamheid vrij laag ligt: elke fout, ook de lichtste fout, volstaat.

96. Om het begrip onachtzaamheid naar boven af te lijnen moet de stap naar het eventueel opzet worden gezet. Het eventueel opzet wordt omschreven als de ondergrens van het opzetbegrip ${ }^{324}$ of met andere woorden de bovengrens van onachtzaamheid.

97. Bewuste onachtzaamheid en eventueel opzet liggen niet zover uiteen, vandaar dat de bewuste onachtzaamheid ook culpa dolo proxima wordt genoemd. Het onderscheidend criterium is het gewild zijn van de gevolgen van de daad of het verzuim. Bij bewuste onachtzaamheid heeft de dader die gevolgen onder geen voorwaarde gewild. Hij kon zich wel indenken dat de gevolgen zich zouden voordoen, maar hij heeft toch gehandeld of nagelaten omdat hij erop rekende dat het niet tot

318 Cass. 30 mei 1932, Pas. I932, I, I76; Cass. 2 I juni I938, AC I938, I38.

319 Cass. 4 mei I982, AC I98I-82, I076.

320 Cass. 24 maart 1999, P.97.I357.F, AC I999, 42I.

321 Cass. 23 juni 1913, Pas. I913, I, 346; Cass. 29 oktober 1934, Rev. dr. pén. 1935, 3 I.

322 Cass. 8 juni 20II, P.II.0570.N, JT 20II, 490, concl. D. Vandermeersch.

323 Cass. 2 mei ig6o, Pas. I96o, I, Ior8.

324 A. Prins, Science pénale et droit positif, Brussel: Bruylant I899, p. I8I, nr. 305; J. Verhaegen, 'Faute consciente ou intention coupable? La ligne de partage', JT 200I, 305 e.v. 
die gevolgen zou komen. Bij eventueel opzet heeft de dader de gevolgen erop de koop toegenomen of anders gezegd hij heeft ze aanvaard, ${ }^{325}$ als een soort collateral dammage. ${ }^{226}$

98. Er zullen in de praktijk nogal wat randgevallen zijn waarbij het niet zo evident is om te bepalen of de dader de niet-gewilde gevolgen van zijn gewild gedrag of verzuim heeft voorzien en heeft aanvaard, dan wel of hij ze niet heeft aanvaard. ${ }^{327}$ Bij het roekeloos negeren van een verkeerslicht om tijdig op zijn werk te komen en zo een dodelijk verkeersongeval veroorzaken, kan moeilijk worden voorgehouden dat uit die enkele omstandigheden blijkt dat de dader de gevolgen op de koop toe heeft genomen. ${ }^{28}$ Van hij die weet dat hij seropositief is en die zonder zijn partner op de hoogte te brengen onveilige seks heeft en zo de partner besmet, zou men kunnen zeggen dat hij zich van de schadelijke gevolgen bewust was en ze heeft aanvaard. ${ }^{329}$ Uiteindelijk komt het de feitenrechter toe om de lijn te trekken tussen de bewuste onachtzaamheid en het eventueel opzet, ${ }^{33^{\circ}}$ waarbij als principe werd vooropgesteld dat bij twijfel de minst zware kwalificatie moet worden aangenomen. ${ }^{33 \mathrm{r}}$

\section{De kritiek op de theorie van de eenheid van strafrechtelijke en burgerrechtelijke fout}

\section{I. Algemeen}

99. Sinds meer dan een halve eeuw wordt de theorie van de eenheid van strafrechtelijke en civielrechtelijke fout en haar gevolgen door een belangrijk gedeelte van de Belgische - overwegend maar niet uitsluitend Franstalige ${ }^{32}$ - doctrine bekritiseerd.

325 Dupont-Verstraeten, p. 256, nr. 438 en p. 258, nr. 445; Hennau-Verhaegen, Droit pénal général 2003, p. 34I-342, nr. 385; Van den Wyngaert, Strafrecht \& Strafprocesrecht 2011, 316; Vanhoudt-Calewaert, II, p. 339-340, nr. 662; J. Verhaegen, 'La définition de l'intention coupable dans les codes pénaux modernes', in: Liber Amicorum Frédéric Dumon, Antwerpen: Kluwer 1983, p. 529. Zie voor een kritiek op het aanvaardingscriterium: W. Brosens, 'Het morele bestanddeel der misdrijven en het toekomstige strafwetboek', l.c., I8I5-I82I.

326 Colette-Basecqz en Blaise, Manuel de droit pénal général, p. 263.

327 Hennau-Verhaegen, Droit pénal général 2003, p. 342 nr. 386.

328 Vgl. Haus, Principes généraux du droit pénal belge, I, p. 237, noot 2.

329 Vgl. B. Ketels, 'De strafrechtelijke context van risicovol seksueel gedrag', T. Strafr. 2008, 360-362, nr. I5-I6; A. Masset, 'Viol entre époux - Sodomie - Sida. Quelques réflexions de droit pénal à propos de l'intégrité sexuelle', JT I989, 2 I.

330 Van den Wyngaert, Strafrecht \& Strafprocesrecht 2011, 3 I6.

33 I O. Michiels, 'Quelques précisions sur les notions de faute, de dol éventuel et de dol praeter-intentionnel quand il y a mort d'homme', (noot onder Corr. Verviers 27 februari 2008), l.c., 493, nr. 7.

332 O.m. R. Dalcq, Traité de la responsabilité civile, I, Les causes de la responsabilité, in: Les Novelles. Droit civil, I/5, Brussel: Larcier I967, p. Io8, nr. I2bis; R. Dalcq, 'Examen de jurisprudence (I963 à I967). La responsabilité délictuelle et quasi délictuelle', RCJB I968, 200-20I, nr. 7; R. Dalcq, 'Faute civile et faute pénale ...', l.c., 73 e.v.; R Dalcq, 'Bijlage II. Consultation de m. le professeur Roger O. Dalcq concernant la responsabilité pénale et la responsabilité civile', in: Beschouwingen van de Commissie over het voorontwerp van Strafwetboek, Brussel: Ministerie van Justitie, I986, p. 69-70; R. Dalcq, 'La prévisibilité du dommage est-elle une condition nécessaire de la faute', l.c., p. 83 e.v. R. Dalcq, noot onder Cass. I5 februari I99I, JT I99I, 742 ; R. Dalcq en G. Schamps, 'Examen de 
Ioo. Hierna worden de grote lijnen van die kritiek overlopen:

- de regel van de eenheid van fouten zou niet uit de parlementaire voorbereiding kunnen worden afgeleid;

- het strafrecht moet zich niet inlaten met onachtzaamheid en de doelstellingen van het strafrecht en het civiele recht zijn te verschillend;

- het foutbegrip wordt objectief en niet subjectief benaderd en met de lichtste fout is de ondergrens te laag;

- de strafrechter zou zijn beslissing over de fout laten afhangen van de belangen van de slachtoffers;

- de negatieve gevolgen van het gezag van strafrechtelijk gewijsde voor de civiele rechter;

- de ongunstige verjaringsregeling van de op een misdrijf gesteunde civiele rechtsvordering;

- de verschillen in bewijsvoering tussen straf- en civiel recht;

- de toepassing van de causaliteitsregel uit het civiele aansprakelijkheidsrecht past niet in het strafrecht.

\subsection{De wetsgeschiedenis}

Ior. Zoals hierboven reeds werd aangegeven heeft het Hof van Cassatie na de inwerkingtreding van het Strafwetboek van $\mathrm{I} 867$ en nadat sommige feitenrechters in andere zin hadden geoordeeld, ${ }^{333}$ vrij snel de regel van de identiteit van fouten aangenomen. Aangezien er vóór de inwerkingtreding van het Strafwetboek van I867 op

jurisprudence (I987 à I993). La responsabilité délictuelle et quasi délictuelle', RCJB I995, 550-55I, nr. I7; R. Dalcq, 'Problèmes actuels en matière de causalité', RGAR I996, nr. I2.656/2 ; P. Delvaux, m.m.v. G. Schamps, 'Unité ou dualité des fautes pénale et civile: les enjeux d'une controverse', RGAR I99I, nr. II.795; P. Delvaux, 'Réflexions sur certains effets seconds de al dissociation entre faute pénale et faute civile', Ann. Dr. Louvain I983, II2 e.v.; J. D’Haenens, 'L'incrimination non intentionnelle dans le droit pénal codifié et réglementaire', Rev. dr. pén. I994, 464-466; Y. Hannequart, La responsabilité pénale de l'ingénieur, Luik: Vaillant-Carmanne I959, p. I65 e.v., nr. I58 e.v.; Y. Hannequart, 'Faute civile - faute pénale: perspectives de réforme', Ann. Dr. Louv. I983, 87 e.v.; C. Hennau-Hublet, L'activité médicale et le droit pénal. Les délits d'atteinte à la vie, l'intégrité physique et la santédes personnes, Brussel: Bruylant I987, p. 368 e.v., nr. 737 e.v.; Hennau-Verhaegen, Droit pénal général 2003, p. 355-356, nr. 4I2; A. Kohl, 'L'action civile en dommages-intérêts résultant d'une infraction. Charge de la preuve de la cause de justification et autorité de chose jugée de la décision répressive antérieure', (noot onder Cass. 7 september I972), RCJB I975, 372 e.v.; C.Hennau-Hublet en G. Schamps, 'Responsabilité pénale et responsabilité civile: une parente contestée', Ann. Dr. Louvain 1995, II3 e.v.; A. Meeus, 'Faute pénale et faute civile', RGAR I992, nr. II.900; G. Schamps, 'Unité des fautes civile et pénale: une brèche', (noot onder Cass. I5 februari I99I), JLMB I99I, II65; G. Schamps, 'Le relâchement des liens entre les responsabilité pénale et civile....', l.c., 4I5 e.v.; G. Schamps, 'La subsidiarité du droit pénal par rapport au droit de la responsabilité civile: la problématique de la responsabilité des prestataires de soins de santé', in: F. Delpérée (red.), Le principe de subsidiarité, Brussel: Bruylant 2002, p. I6o e.v.; Van den Wyngaert, Strafrecht \& Strafprocesrecht 2011, p. 30I-303; J. Verhaegen, 'L'imprudence punissable en législation et en jurisprudence belges', JT I979, 349 e.v.; J. Verhaegen, 'Vers l'abandon d'une jurisprudence séculaire. A propos de la proposition de loi $n^{\circ} 298 / 2000$ abolissant la théorie de l'unité des fautes pénale et civile', JT 200I, 5 I6.

333 Zie Y. Hannequart, La responsabilité pénale de l'ingenieur, Luik: Vaillant-Carmanne I959, p. I66-I67, nr. I6I. 
dit punt nagenoeg geen rechtspraak bestond, kan moeilijk worden gesteld dat het Hof daarmee afbreuk deed aan de vroegere rechtspraak. ${ }^{334}$

I02. Met verwijzingen naar de parlementaire voorbereiding en geschriften van Nypels heeft A. Meeus ${ }^{335}$ aangetoond dat, anders dan door sommigen wordt aangevoerd, ${ }^{336}$ de regel van de lichtste fout en de regel van de identiteit van strafrechtelijke en civielrechtelijke fout wel degelijk steun vinden in de opvattingen van de strafwetgever, ook al was die strafwetgever zich waarschijnlijk niet bewust van de problemen die een en ander kon opleveren:

- volgens Haus omvat het gebrek aan voorzichtigheid of voorzorg alle fouten en werd het bepalen van de graad van fout overgelaten aan de feitenrechter; 337

- volgens het verslag-Forgeur werden alle gevallen van strafbare fout beoogd; $33^{8}$

- Nypels gaf als lid van de Commissie tot hervorming van het Strafwetboek en dus als bevoorrecht commentaar reeds in 1878 , dit is vóór het Hof van Cassatie in die zin oordeelde, aan dat de lichtste fout volstond voor de toepassing van de onopzettelijk letsel-misdrijven. 339

Uit het oordeel dat elke fout, zelfs de lichtste, tot strafrechtelijke en ook tot civielrechtelijke aansprakelijkheid leidt, volgt logischerwijze de regel van de identiteit van fouten.

I03. Er kan niet worden gesteld dat Haus de regel van identiteit van fouten heeft verworpen. Hij blijkt ze integendeel te hebben bevestigd, zij het dat hij blijkbaar aan de gevolgen van die stelling op civielrechtelijk vlak niet heeft gedacht. ${ }^{34^{\circ}}$ Zo schrijft Haus $^{341}$ dat de beoordeling van de aansprakelijkheid van de fout, 'en matière de délits et de quasi-délits', volledig afhankelijk is van de door de rechter te beoordelen omstandigheden, waarmee hij aangeeft dat de beoordelingscriteria voor de strafrechtelijk fout (délits) en de civielrechtelijke fout (quasi-délits) dezelfde zijn. Zijn opvatting dat de fout bestaat in het niet hebben vermeden van datgene wat publieke of private belangen kan schaden ${ }^{342}$ en dat zelfs inzake 'délits' er niet verder moet worden gegaan dan het in het Romeinse recht gehanteerde criterium, ${ }^{343}$ bevestigen dit.

334 Meeus, 'Faute pénale et faute civile', l.c., nr. II.9oo/I verso.

335 Meeus, 'Faute pénale et faute civile', l.c., nr. II.90o/I verso-2recto.

336 Bijv.Verslag commissie herziening strafwetboek, p. 82; P. Delvaux, m.m.v. G. Schamps, 'Unité ou dualité des fautes pénale et civile ...', l.c., nr. II.795/Iverso; G. Schamps, 'Unité des fautes civile et pénale: une brèche', l.c., p. II65-II66.

337 Nypels, Législation criminelle, III, nr. Io6 in fine.

338 Nypels, Legislation criminelle, III, p. 388, nr. I6 in fine.

339 Nypels, Le code pénal belge interprété, Brussel: Bruylant I878, II, p. 437.

340 Meeus, 'Faute pénale et faute civile', l.c., nr. II.90o/2recto.

34I Nypels, Législation criminelle, III, nr. I03, al. 3.

342 Nypels, Législation criminelle, III, nr. I03, al. I.

343 Nypels, Législation criminelle, III, nr. I03, al. 2. 


\subsection{Het strafrecht hoeft zich niet in te laten met onachtzaamheid}

I04. Het strafrechtelijk subsidiariteitsbeginsel houdt in dat het strafrecht slechts dan moet worden ingezet indien het met de strafrechtelijke benadering beoogde resultaat niet kan worden bekomen door middel van het gebruik van een andere, minder dwingende of minder stigmatiserende rechtstak. ${ }^{344}$ In dat licht kan de vraag worden gesteld of de onachtzaamheidsmisdrijven wel hun plaats hebben in het strafrecht. ${ }^{345}$ Vooral in de medische sector wordt het nut van de strafbaarstelling van tot onopzettelijk letsel aanleiding gevende beroepsfouten betwijfeld. ${ }^{346}$ Aangehaald wordt dat beroepsfouten van andere (vrije) beroepen in de praktijk niet tot strafrechtelijke aansprakelijkheid leiden ${ }^{347}$ en dat een strafrechtelijke aanpak van beroepsfouten geen preventief effect heeft, niet leidt tot een betere zorg en bovendien aanzet tot een meer defensieve geneeskunde. ${ }^{348}$

I05. De regel van de identiteit van de fouten werd ook bekritiseerd omdat hij niet te rijmen zou vallen met het verschil in doelstellingen van de civielrechtelijke aansprakelijkheid en de strafrechtelijke verantwoordelijkheid. ${ }^{349}$ Het strafrecht beoogt bestraffing en het accent ligt er niet alleen op de strafbare daad, maar ook op de dader en zijn persoon. In het civiele recht waar de fout maar een van de gronden is die tot aansprakelijkheid leidt, draait de zaak meer rond het slachtoffer. ${ }^{35^{\circ}}$

\subsection{Het foutbegrip wordt objectief in plaats van subjectief benaderd en met de lichtste fout ligt de ondergrens te laag}

Io6. Het hanteren van het abstract criterium van de NVR-persoon en dus zonder acht te slaan op de persoonlijke kenmerken van de dader wordt door de meerderheid van de rechtsleer bekritiseerd. Die kritiek vindt steun in de parlementaire voorbereiding van het Strafwetboek van 1867 en in het bijzonder in het verslag-Haus. Haus ${ }^{351}$ gaf aan het begrip strafrechtelijke fout een zeer subjectief karakter:

'L'appreciation de la faute et de ses divers degrés est donc abandonnée à la conscience éclairée du juge qui, dans chaque cas partiuclier, doit prendre en considération l'âge, le sexe et les autres qualités personnelles du prévenu, la nature et les circonstances de l'acte qui a produit l'infraction'.

344 Schamps, 'La subsidiarité du droit pénal par rapport au droit de la responsabilité civile ..., l.c., p. I6r, nr. I.

345 Tulkens en Van de Kerchove, Introduction au droit pénal, p. 393.

346 Van Overbeke, 'De arts in de beklaagdenbank. ...' l.c., p. 936-937.

347 J. De Toeuf, 'La réparation des accidents thérapeutiques. Responsabilité sans faute', in: T. Vansweevelt en J. Fagnart e.a. (red.), Aansprakelijkheid en medische ongevallen. Responsabilité et accidents médicaux, Gent: Mys \& Breesch 1996, p. I4I.

348 Schamps, 'La subsidiarité du droit pénal par rapport au droit de la responsabilité civile ..., l.c., I66, nr. 7.I.

349 O.m. Verslag commissie herziening strafwetboek, p. 8o-8I.

350 Delvaux, m.m.v. Schamps, 'Unité ou dualité des fautes pénale et civile ..., l.c., nr. Ir.795/2recto.

35I Haus, Principes généraux du droit pénal belge, I, p. 234, nr. 323; G. Nypels, Législation, III, 240, nr. 103, al. 4 . 
Hij plaatste die in zijn ogen moderne opvatting tegenover die van het Romeinse recht, dat vereist dat 'que chacun prenne dans ses actions les soins d'un bonne père de famille, un homme essentiellement prudent et attentif, à l'habitude d'employer', wat een abstract criterium is, dat thans wordt gehanteerd voor de beoordeling van de civielrechtelijke fout.

I07. De meerderheid van de rechtsleer ${ }^{352}$ acht het abstracte toetsingscriterium misschien wel geschikt voor de beoordeling van de burgerrechtelijke aansprakelijkheid, maar niet voor de strafrechtelijke aansprakelijkheid. Die aansprakelijkheid moet zowel wat betreft het aspect van de onachtzaamheid als de voorzienbaarheid van schade worden beoordeeld rekening houdend met de persoonlijke kenmerken van de dader zoals zijn leeftijd, geslacht, gezondheidstoestand, eigen capaciteiten en geestesvermogen, opleiding en ervaring. Of foutief is gehandeld moet worden beoordeeld in het licht van de concrete omstandigheden van de zaak en rekening houdend met de persoonlijke eigenschappen van de betrokkene. Dat was ook de opvatting van de Commissie voor de herziening van het Strafwetboek. 353 De beoordeling dient dus geheel in concreto te gebeuren.

I08. De culpa levissima-drempel wordt door sommigen als bijzonder streng en dus te streng ervaren. ${ }^{354}$ Zware fout (culpa lata) zou de minimumdrempel moeten zijn en culpa levissima zou enkel tot civielrechtelijke aansprakelijkheid mogen leiden. ${ }^{355}$ Ook de Commissie voor de herziening van het Strafwetboek verdedigde de stelling dat enkel laakbare onachtzaamheid tot strafrechtelijke aansprakelijkheid aanleiding zou mogen geven..$^{35}$ Verschillende argumenten worden aangehaald:

- volgens het strafrechtelijke subsidiariteitsbeginsel zou enkel de zware fout (culpa lata) en niet de lichtste fout (culpa levissima) mogen worden bestraft; 357

352 Colette-Basecqz en Blaise, Manuel de droit pénal général, 263-264; R. Dalcq, 'Faute civile et faute pénale ...', l.c., 77-78; P. Delvaux, m.m.v. G. Schamps, 'Unité ou dualité des fautes pénale et civile ..., l.c., nr. II.795/3recto ; C. Hennau-Hublet, 'L'activité médicale et les délits d'atteinte à la vie ...', l.c., 590; Y. Hannequart, 'Faute civile - faute pénale ...' l.c., Io4 e.v.; C. Hennau-Hublet, 'L'action civile fondée sur le délit de coups et blessures par imprudence', l.c., II.938/3; C. Hennau-Hublet, 'La responsabilité pénale pour coups et bléssures involontaires en raison d'un comportement d'omission', l.c., p. 331-332; Hennau-Verhaegen, Droit pénal général 2003, p. 343-344, nr. 39I-392, p. 348, nr. 397 en p. 354-355, nr. 4I0-4II; A. Kohl, 'L'action civile en dommages-intérêts résultant d'une infraction..., l.c., p. 38I, nr. 7 ; A. Meeus, 'Faute pénale et faute civile', l.c., nr. II.900/2recto3verso ; O. Michiels, 'Quelques précisions sur les notions de faute, de dol éventuel et de dol praeter-intentionnel quand il y a mort d'homme', (noot onder Corr. Verviers 27 februari 2008), l.c., p. 492, nr. 3; G. Schamps, 'La subsidiarité du droit pénal par rapport au droit de la responsabilité civile ..., l.c., p. I64, nr. 6.I., p. I67, nr. 7.3 en p. I72, nr. 9 ; J. Verhaegen, 'Vers l'abandon d'une jurisprudence séculaire. ... ', l.c., p. $5 \mathrm{I} 6$.

353 Verslag commissie herziening strafwetboek, p. 8I-82.

354 R. Dalcq, 'Examen de jurisprudence (I963 à I967) ..., l.c., p. 20I, nr. 7; Van den Wyngaert, Strafrecht \& Strafprocesrecht 2011, p. 302.

355 Van den Wyngaert, Strafrecht \& Strafprocesrecht 2011, p. 303.

356 Verslag commissie herziening strafwetboek, p. 8I.

357 J. D’Haenens, 'L'incrimination non intentionnelle dans le droit pénal codifié et réglementaire', Rev. dr. pén. I994, p. 464; Van den Wyngaert, Strafrecht \& Strafprocesrecht 2011, p. 303. 
- elke fout strafrechtelijk sanctioneren zou niet te rijmen zijn met de doelstellingen van het strafrecht. ${ }^{35^{8}} \mathrm{Zij}$ die slechts een onbelangrijke fout hebben begaan, behoeven geen aandacht van de strafrechter. ${ }^{359}$ De bescherming van het leven en van de fysieke integriteit zouden niet zo absoluut te zijn dat ook een aantasting ingevolge een lichte fout binnen het strafrechtelijk domein moet vallen; ${ }^{36}$

- vooral in de medische sector wordt de nood aangevoeld om een onderscheid te maken tussen lichte en zware beroepsfouten ${ }^{361}$ of de strafrechtelijke aansprakelijkheid te beperken tot de gevallen van een duidelijke miskenning van de beroepsplichten; ${ }^{362}$

- sinds het aannemen van de theorie van de eenheid van fouten is de samenleving ingrijpend gewijzigd: er zijn de veranderingen op industrieel en technologisch vlak, de steeds maar toenemende maatschappelijke complexiteit, de ongebreidelde regelgeving, de snelheid waarmee alles moet gebeuren en de daaruit voortvloeiende druk die op elkeen weegt. Dit maakt dat elkeen, zelfs bij een maximaal streven naar voorzichtigheid en voorzorg, onvermijdelijk fouten maakt op professioneel en sociaal vlak. In de mate dat die fouten niet bijzonder zwaar zijn, behoeven ze geen strafrechtelijke reactie. Een minder simplistisch en routinematig concept van de fout zou moeten worden gehanteerd..$^{363}$

\subsection{De rechter zou zijn beslissing over de fout laten afhangen van de belangen van de slachtoffers.}

I09. In de rechtsleer werd geopperd dat de rechter zou aarzelen om de beklaagde vrij te spreken teneinde zo de slachtoffers niet in de kou te laten staan ${ }^{364}$ of dat de omstandigheid dat de civiele aansprakelijkheid van de beklaagde is gedekt door een verzekering de rechter ertoe zou brengen de beklaagde schuldig te verklaren om de slachtoffers van een schadeloosstelling te verzekeren, maar dat hij dan mild zou zijn door het verlenen van een straf met uitstel of de opschorting van de uitspraak veroordeling. ${ }^{365}$ Ook de Commissie voor de herziening van het Strafwetboek verdacht de strafrechter ervan om bij de schuldbeoordeling rekening te houden met

358 G. Schamps, 'La subsidiarité du droit pénal par rapport au droit de la responsabilité civile ..., l.c., p. $\mathrm{I}_{3}$, nr. 4 .

359 P. Delvaux, m.m.v. G. Schamps, 'Unité ou dualité des fautes pénale et civile ...', l.c., nr. II.795/Iverso.

360 G. Schamps, 'La subsidiarité du droit pénal par rapport au droit de la responsabilité civile ..., l.c., p. 164, nr. 6.I.

36r R. Dalcq, 'Examen de jurisprudence (ig63 à I967) .., l.c., p. 220, nr. 28 ; R. Declercq, 'Enkele problemen i.v.m. de toepassing van de artikelen 4I8, $4 \mathrm{I} 9$ en 420 van het Strafwetboek', l.c., p. $20 \mathrm{I}$.

362 De Nauw, Bijzonder strafrecht 2010, p. 217, nr. 269. Zie ook: Corr. Neufchâteau 26 mei I983, Rev. dr. pén. I983, p. 809.

363 A. Meeus, 'Faute pénale et faute civile', l.c., nr. II.90o/2verso.

364 Dupont-Verstraeten, p. 26o, nr. 449; Hennau-Verhaegen, Droit pénal général 2003, p. 344, nr. 392; A. Kohl, 'L'action civile en dommages-intérêts résultant d'une infraction...', l.c., p. 382, nr. 8; F. Rigaux, 'L'érosion de l'autorité "erga omnes" de la chose jugée au pénal par la primauté du droit au procès équitable', (noot onder Cass. I5 februari I99I), RCJB I992, I2, nr. 4.

365 G. Schamps, 'La subsidiarité du droit pénal par rapport au droit de la responsabilité civile ...', l.c., p. 165, nr. 6.2. 
het vergoeden van de slachtoffers ${ }^{366}$ en ook parlementsleden die een wetsvoorstel indienden om de regel van de eenheid van fouten te doorbreken, gingen daarvan uit. ${ }^{67}$

IIo. Er werd echter ook aangevoerd dat de strafrechter bij lichtere fouten niet snel geneigd zou zijn te veroordelen en daarom wegens twijfel zou vrijspreken, met als gevolg dat de vordering van de schadelijder wordt afgewezen. ${ }^{368}$

\subsection{Het gezag van het strafrechtelijk gewijsde voor de civiele rechter}

III. De kritiek op de regel van de eenheid van fouten richt zich in voorname mate op het gezag van gewijsde dat kleeft aan de beslissing van de strafrechter voor de civiele rechter. ${ }^{69}$ Volgens het algemeen rechtsbeginsel van het gezag van het strafrechtelijk gewijsde, dat sommigen vastknopen aan artikel 4 VT Sv., ${ }^{370}$ geldt de definitieve uitspraak van de strafrechter over de strafvordering, die de openbare orde raakt, erga omnes en bindt die dus ook de civiele rechter. De beslissingen over de strafvordering komen bijgevolg niet meer ter sprake voor de civiele rechter. In zoverre de betwisting voor de civiele rechter betrekking heeft op hetzelfde feit waarover de strafrechter heeft geoordeeld, is de rechter gebonden door datgene wat de strafrechter zeker en noodzakelijk heeft beslist. ${ }^{37 \mathrm{I}}$

II2. Toegepast op een onopzettelijk letsel-misdrijf heeft het gezag van het strafrechtelijk gewijsde tot gevolg dat indien de strafrechter zeker en noodzakelijk heeft beslist dat niet is bewezen dat de beklaagde een fout heeft begaan, zelfs wegens twijfel, dit oordeel zich opdringt aan de civiele rechter en die rechter bijgevolg die beklaagde in een daarop volgend civiel proces niet meer kan veroordelen tot schadeloosstelling van het slachtoffer. ${ }^{372}$

II3. Er moet worden onderstreept dat het gezag van strafrechtelijk gewijsde van een vrijspraak niet elke vordering van de schadelijder tegenover de beklaagde voor de civiele rechter belet. Zo blijft een vordering voor de civiele rechter mogelijk indien die niet is gesteund op een fout in de zin van de artikelen ${ }_{13} 82-I_{3} 83 \mathrm{BW}$, maar op een andere aansprakelijkheidsregel. ${ }^{373}$

366 Verslag commissie herziening strafwetboek, p. 78 .

367 Parl. St. Kamer, I997-98, nr. I574/I, 3; Parl. St. Kamer, 2007-08, nr. 52-II70/oor.

368 R. Dalcq, 'Faute civile et faute pénale ...', l.c., p. 8I.

369 Verslag commissie herziening strafwetboek, p. 78; R. Dalcq, 'Faute civile et faute pénale ...', l.c., p. 82-84; P. Delvaux, m.m.v. G. Schamps, 'Unité ou dualité des fautes pénale et civile ...', l.c., nr. II.795/4recto; A. Kohl, 'L'action civile en dommages-intérêts résultant d'une infraction...', l.c., p. 382-389, nr. 9-I3; G. Schamps, 'La subsidiarité du droit pénal par rapport au droit de la responsabilité civile ..., l.c., p. I67-169, nr. 7·3.

370 Colette-Basecqz en Blaise, Manuel de droit pénal général, p. 264; P. Delvaux, m.m.v. G. Schamps, 'Unité ou dualité des fautes pénale et civile ...', l.c., nr. II.795/4recto ; G. Schamps, 'Unité des fautes civile et pénale: une brèche', l.c., II65.

37 I R. Declercq, Beginselen van Strafrechtspleging 2010, p. I366-г369, nr. 3353-3358.

372 Bijv. Cass. I9 februari I988, AC I987-88, 795.

373 R. Dalcq, 'Faute civile et faute pénale ...', l.c., p. 83. 
II4. Het absoluut karakter van het gezag van strafrechtelijk gewijsde heeft ingevolge de op artikel 6 EVRM gesteunde cassatierechtspraak ${ }^{374}$ een flinke deuk gekregen: hij die geen partij was in het strafproces of er zijn belangen niet heeft kunnen verdedigen, mag voor de civiele rechter de uit het strafproces afgeleide gegevens betwisten.

II5. Zelfs rekening houdend met deze matiging van het gezag van strafrechtelijk gewijsde volgt uit de regel van de eenheid van fouten dat bij een vrijspraak voor een onopzettelijk letsel-misdrijf wegens het niet aangetoond zijn van een fout, de schadelijder die zich voor de strafrechter burgerlijke partij had gesteld en werd afgewezen, voor de civiele rechter niet kan aanvoeren dat de beklaagde foutief heeft gehandeld. ${ }^{375}$ Er werd dan ook voor gepleit om aan een vrijspraak wegens de afwezigheid van fout geen gezag van strafrechtelijk gewijsde voor de burgerlijke rechter te verbinden en de burgerlijke rechter zijn beoordelingsvrijheid over de fout te laten behouden. ${ }^{376}$

\subsection{De verjaring van de op een misdrijf gesteunde burgerlijke vordering}

II6. De kritiek op de regel van de eenheid van fouten had ook betrekking op de verjaringsregeling van de op een misdrijf gesteunde civiele rechtsvordering. ${ }^{377}$ Tot en met de wetswijziging van 30 mei I96r gold voor de verjaring van de op het misdrijf gesteunde civiele rechtsvordering eenzelfde termijn als voor de strafvordering. Met die wetswijziging werd die termijn bepaald op vijf jaar, zij het dat die nooit minder kon zijn dan de verjaringstermijn van de strafvordering. De verjaringstermijn voor de op een misdrijf gesteunde civiele rechtsvordering was dus aanmerkelijk korter dan de dertigjarige gemeenrechtelijke verjaringstermijn uit het civiele recht.

II7. Daarbij kwam nog dat volgens de toenmalige rechtspraak die termijn een aanvang nam op het ogenblik dat de schade zich voordeed, ook al had die schade zich nog niet veruitwendigd en was het slachtoffer zich van die schade nog niet bewust. Vooral voor slachtoffers van medische fouten kon die regel onaangename gevolgen hebben: indien de fout interne letsels had veroorzaakt waarvan de gevolgen zich pas na het bereiken van de verjaringstermijn manifesteerden, was geen vordering meer mogelijk. ${ }^{378}$

374 R. Declercq, Beginselen van Strafrechtspleging 2010, p. I374-I375, nr. 337I-3372 en de daar geciteerde rechtspraak.

375 R. Dalcq, noot onder Cass. I5 februari I99I, JT I99I, 742; A. Meeus, 'Faute pénale et faute civile', l.c., nr. II.90o/3recto.

376 G. Schamps, 'La subsidiarité du droit pénal par rapport au droit de la responsabilité civile ...', l.c., p. $167, \mathrm{nr} .7 \cdot 3$.

377 R. Dalcq, 'Faute civile et faute pénale ...', l.c., p. 84-86; P. Delvaux, m.m.v. G. Schamps, 'Unité ou dualité des fautes pénale et civile ...', l.c., nr. II.795/Iverso en 3/verso ; G. Schamps, 'Unité des fautes civile et pénale: une brèche' ..., l.c., ir66; Verslag commissie herziening strafwetboek, p. 85 .

378 R. Dalcq, 'Faute civile et faute pénale ...', l.c., 85-86; A. Meeus, 'Faute pénale et faute civile', l.c., nr. II.90o/3verso; Verslag commissie herziening strafwetboek, p. 86. 
II8. Met het arrest van 13 januari 1994 heeft het Hof van Cassatie ${ }^{379}$ zijn rechtspraak evenwel aangepast. Het oordeelde dat ook al zijn de onopzettelijk letsel-misdrijven aflopende misdrijven die bestaan vanaf het ogenblik van het verenigd zijn van de constitutieve bestanddelen, de verjaring van de op een dergelijk misdrijf gesteunde civiele rechtsvordering slechts een aanvang neemt op het ogenblik dat de schade aan het licht komt..$^{80}$

II9. Met de wet van ig juni 1998 werd het verjaringsstelsel van de op een misdrijf gesteunde civielrechtelijke vordering gewijzigd. Volgens het nieuwe artikel 26 VT Sv. verjaart een dergelijke vordering volgens de regels van het Burgerlijk Wetboek of volgens op de rechtsvordering tot vergoeding van schade toepasselijke bijzondere wetten, zonder echter te kunnen verjaren vóór de strafvordering. Artikel 2262bis Burgerlijk Wetboek bepaalt dat alle rechtsvorderingen tot vergoeding van schade op grond van buitencontractuele aansprakelijkheid verjaren door verloop van vijf jaren vanaf de dag volgend op de dag waarop de benadeelde kennis heeft gekregen van de schade of van de verzwaring ervan en van de identiteit van de daarvoor aansprakelijke persoon, en ieder geval door verloop van twintig jaren vanaf de dag volgend op die waarop het feit waardoor de schade is veroorzaakt, zich heeft voorgedaan.

\subsection{De bewijsregeling}

I20. De bewijsregeling van het civiele recht zoals die is vastgelegd in artikel I3 $_{5} \mathrm{BW}$ wijkt af van die van het strafrecht. In het strafrecht geldt het in artikel 6.2 EVRM opgenomen onschuldvermoeden, moeten alle bestanddelen van het misdrijf worden bewezen en dient een aannemelijk gemaakte schulduitsluitingsgrond te worden weerlegd. De regel van de eenheid van fouten leidt ertoe dat de strafrechtelijke bewijsregeling van toepassing is op schadevorderingen wegens onopzettelijk letsel ongeacht of die vordering voor de straf- of voor de civiele rechter wordt gebracht, ${ }^{38 \mathrm{r}}$ terwijl de aard van die vordering dit niet altijd rechtvaardigt. ${ }^{382}$

\subsection{De causaliteit}

I2I. Ook de beoordeling van de causaliteit in het strafrecht volgens de principes van het civiele aansprakelijkheidsrecht wordt als te streng ervaren. ${ }^{83}$ Een beoordeling

379 Cass. I3 januari I994, AC I994, 27, JT I994, 29I, noot R. Dalcq, R. Cass. I994, II6, noot P. Van Caenegem, RCJB I995, 42I, noot J. Fagnart, Vl. T. Gez. I994-95, 30, noot D. Freriks.

380 Zie: S. Van Overbeke, 'Het aanvangspunt van de verjaringstermijn van de strafvordering bij onopzettelijke slagen en verwondingen', RW 20II-I2, 894-902.

38I P. Delvaux, m.m.v. G. Schamps, 'Unitéou dualité des fautes pénale et civile..., l.c., nr. II.795/2rectoverso; G. Schamps, 'Unité des fautes civile et pénale: une brèche' ..., l.c., II66; A. Kohl, 'L'action civile en dommages-intérêts résultant d'une infraction...', l.c., 380, nr. 6.

382 R. Dalcq, 'La prévisibilité du dommage est-elle une condition nécessaire de la faute', l.c., 89; A. Meeus, 'Faute pénale et faute civile', l.c., nr. Ir.90o/3verso.

383 G. Schamps, 'La subsidiarité du droit pénal par rapport au droit de la responsabilité civile ...', l.c., I64, nr. 6.I en noot (Io). 
volgens de leer van de adequate oorzaak zou meer in overeenstemming zijn met de aard en de doelstellingen van het strafrecht. ${ }^{34}$

\section{Voorstellen tot wijziging}

\section{I. De voorstellen van de Commissie voor de herziening van het Strafwetboek (I979) en van de Koninklijk commissaris voor de hervorming van het Strafwetboek (1985)}

I22. Bij de poging om het Strafwetboek van I867 te herschrijven in het licht van de hedendaagse opvattingen over strafrecht is de problematiek van de eenheid van fouten aan bod gekomen. Hoewel het initiatief geen nieuw Strafwetboek heeft opgeleverd, lijkt het nuttig om kort de ingenomen standpunten te vermelden.

I23. De Commissie voor de herziening van het Strafwetboek, ${ }^{385}$ geïnspireerd door de hierboven besproken kritische doctrine, ${ }^{386}$ was van oordeel dat de rechter bij het bepalen van de gepaste maatschappelijke reactie een grotere beoordelingsbevoegdheid diende te krijgen: ofwel straf en herstel van de schade ofwel enkel een civielrechtelijke sanctie. De Commissie stelde daartoe twee technieken voor:

- de dualiteit van de strafrechtelijke en civielrechtelijke fout en dus het afschaffen van de regel van de eenheid van fouten. De identiteit van fouten werd strijdig geacht met de recente opvattingen over de onderscheiden doelstellingen van de straf- en civielrechtelijke aansprakelijkheid (respectievelijk schadeherstel en afkeuring-afschrikking). De objectiveringstendens in het civiel aansprakelijkheidsrecht en een toetsing zonder rekening te houden met persoonlijke kenmerken van de dader leek onverenigbaar met het strafrechtelijk foutbegrip; ${ }^{387}$

- het behoud van de regel van de eenheid van fouten in combinatie met de dualiteit van hun gevolgen: straf- en civielrechtelijke fout worden op dezelfde wijze beoordeeld, maar een vrijspraak zou de civiele rechter niet meer binden. Indien de strafrechter zou oordelen dat de fout op persoonlijke gronden verschoonbaar is, zou hij zich kunnen beperken tot een eenvoudige schuldigverklaring en zich uitspreken over de schade-eis. ${ }^{38}$

384 Colette-Basecqz en Blaise, Manuel de droit pénal général, 264 en noot (648); R. Dalcq, 'Faute civile et faute pénale ..., l.c., p. 78-79; R. Dalcq, 'La prévisibilité du dommage est-elle une condition nécessaire de la faute', l.c., 88; P. Delvaux, m.m.v. G. Schamps, 'Unité ou dualité des fautes pénale et civile ...', l.c., nr. II.795/3recto; A. Meeus, 'Faute pénale et faute civile', l.c., nr. II.90o/3recto.

385 Verslag commissie herziening strafwetboek, p. 78-79.

386 R. Dalcq, 'Faute civile et faute pénale ...', l.c., p. 76.

387 Verslag commissie herziening strafwetboek, p. 80-83; J. D'Haenens, 'L'incrimination non intentionnelle dans le droit pénal codifié et réglementaire', Rev. dr. pén. I994, p. 465-466; J. Verhaegen, 'Vers l'abandon d'une jurisprudence séculaire. ...', l.c., p. $5 \mathrm{I} 6$.

388 Verslag commissie herziening strafwetboek, p. 84-85; J. D'Haenens, 'L'incrimination non intentionnelle dans le droit pénal codifié et réglementaire', Rev. dr. pén. I994, p. 465-466. 
I24. Voor die misdrijven waar de niet gewilde gevolgen van een handeling een misdrijfbestanddeel zijn, wat het geval is bij de onopzettelijk letsel-misdrijven, stelde de Commissie voor om in het Strafwetboek in te schrijven dat het oorzakelijk verband diende te worden beoordeeld volgens de leer van de adequate oorzaak en dus niet volgens de in het civiel aansprakelijkheidsrecht gangbare equivalentieleer. ${ }^{389}$ Dit voorstel houdt in dat wordt afgestapt van de regel van de eenheid van fouten..$^{390}$

I25. Waar de Commissie voor de herziening van het Strafwetboek dus pleitte voor de afschaffing, in ieder geval voor een grondige aanpassing van de regel van de eenheid van fouten, neemt Koninklijk Commissaris R. Legros die regel van eenheid van fouten en de op dit vlak gevestigde rechtspraak in zijn voorontwerp over. ${ }^{391}$ In het voorgestelde wetsontwerp bepaalt artikel ro dat bij strafbare feiten uit onvoorzichtigheid de rechter, behoudens bijzondere bepalingen, rekening houdt met de lichtste schuld, terwijl er volgens artikel 66 moet worden getoetst aan het gedrag van een redelijk, voorzichtig en zorgvuldig persoon, zonder dat melding wordt gemaakt van de persoonlijke kenmerken van de dader. ${ }^{392}$

\subsection{Het voorstel-Meeus}

I26. A. Meeus ${ }^{393}$ heeft in 1992 naar aanleiding van een aan UCL georganiseerd seminarie over 'Les enjeux d'une dissociation des fautes pénale et civile' voorgesteld de artikelen $4 \mathrm{I} 8$ en $420 \mathrm{Sw}$. als volgt te wijzigen:

'Art. 418. Est coupable d'homicide ou de lésion involontaire, celui qui a causéle mal par une faute résultant d'un défaut de prévoyance ou de précaution, mais sans intention d'attenter à la personnen d'autrui.

Art. 420. S'il n'est résulté de la faute prévue à l'article 418 que les coups et les blessures, le coupable seri puni d'un emprisonnement de huit jours à six mois et d'une amende de cinquante francs à cinqs cents francs ou d'une de ces peines seulement.'

I27. Op die manier wil Meeus een onderscheid maken tussen strafrechtelijke en civielrechtelijke fout, wat volgens hem overeenstemt met de maatschappelijke realiteit. ${ }^{394}$ Om het onderscheid te maken is de zwaarte van de fout een beoordelingselement, maar niet het enige. De lichte of de occasionele fout wordt uit het strafrecht gebannen. Alleen indien het gebrek aan voorzichtigheid of voorzorg bestaat in nonchalance (la désinvolture), achteloosheid (la négligence) of een gebrek aan respect voor een ander, is het strafrecht op zijn plaats en het komt de rechter toe

389 Verslag commissie herziening strafwetboek, p. 65-66.

390 F. Rigaux, 'L'érosion de l'autorité 'erga omnes' ..., l.c., I3, nr. 5.

39 I R. Legros, Voorontwerp van Strafwetboek, Brussel: Ministerie van Justitie 1985, p. I35-I37 (hierna: Voorontwerp van Strafwetboek).

392 Voorontwerp van Strafwetboek, p. I2 en 2 I.

393 A. Meeus, 'Faute pénale et faute civile', l.c., nr. II.90o/3verso.

394 A. Meeus, 'Faute pénale et faute civile', l.c., nr. II.9oo/2verso. 
om te oordelen of aan die voorwaarde is voldaan. ${ }^{395}$ De civielrechtelijke fout die tot schadevergoedingsplicht leidt, bestaat onafhankelijk van elke strafrechtelijke fout en die regel wordt in artikel $\mathrm{I}_{3} 83 \mathrm{BW}$ ingeschreven. De verjaringsregels van het burgerlijk recht zijn van toepassing en de civiele rechter is niet gebonden door een vrijspraak door de strafrechter aangezien hij oordeelt over een soort fout volgens andere criteria. ${ }^{396}$

\subsection{Wetsvoorstellen}

I28. De laatste vijfentwintig jaar zijn diverse wetsvoorstellen ingediend om op de een of andere manier de regel van de eenheid van fouten te doorbreken. Gemeenschappelijk aan die wetsvoorstellen is dat ze in meer of mindere mate geïnspireerd zijn door de voormelde kritische rechtsleer inclusief het voorstel-Meeus. Gemeenschappelijk is ook het resultaat: ze vervielen alle ingevolge een ontbinding van het parlement, meestal zonder grondige bespreking. Niettemin lijkt het wenselijk de belangrijkste uitgangspunten van de voorstellen te schetsen.

I29. Een op 3 mei I99I ingediend wetsvoorstel ${ }^{397}$ had als bedoelding om de civiele rechter bij de beoordeling van de civielrechtelijke aansprakelijkheid een volledige beoordelingsvrijheid te geven en dus ongeacht wat de strafrechter had beslist. Het strekt ertoe om artikel 4 VT Sv. aan te vullen met een lid, waarin werd bepaald dat de burgerlijke rechter niet gebonden is door een door de strafrechter verleende vrijspraak, noch wat betreft het bestaan van de schuld noch wat betreft de onderscheidingsbekwaamheid. Daarmee werd impliciet aangegeven dat de strafrechter en de civiele rechter een eigen foutbegrip konden hanteren.

I30. De op 28 mei I998, 28 juli I998 en I7 januari 2000 ingediende wetvoorstellen ${ }^{398}$ lagen in dezelfde lijn. In een nieuw in te voegen artikel 1383 bis BW werd bepaald dat de beoordeling van de nalatigheid en de onvoorzichtigheid in het civiele recht zou geschieden volgens eigen normen en dit ongeacht de beoordeling van de strafrechtelijke schuld en de beslissing van de strafrechter zou zich niet meer opdringen aan de strafrechter. Teneinde een extra procedure te vermijden, zou de strafrechter ook in geval van vrijspraak bevoegd blijven om uitspraak te doen over de civiele rechtsvordering volgens de normen van het civiele recht, op voorwaarde dat hij daartoe werd verzocht door de burgerlijke partij of haar verzekeraar. ${ }^{399} \mathrm{Bij}$ afwezigheid van een dergelijk verzoek zou de strafrechter de zaak moeten doorverwijzen naar de civiele rechter waar ze kosteloos op de rol zou worden ingeschreven. ${ }^{400}$ Op die

395 A. Meeus, 'Faute pénale et faute civile', l.c., nr. II.90o/2verso, 3/verso en 4/recto.

396 A. Meeus, 'Faute pénale et faute civile', l.c., nr. II.90o/2verso en $4 /$ verso.

397 Parl. St. Kamer, I990-9I, nr. I607/I.

398 Parl. St. Kamer, I997-98, nr. I574/I en 2; Parl. St. Senaat, I997-98, nr. I085/I; Parl. St. Senaat, I999oo, nr. 2-298/I; J. Verhaegen, 'Vers l'abandon d'une jurisprudence séculaire. ... ', l.c., 517.

399 Parl. St. Kamer, I997-98, nr. I574/3; Parl. St. Senaat, I999-00, nr. 2-298/I.

400 Parl. St. Senaat, I999-0o, nr. 2-298/I. 
manier zouden de belangen van de beklaagde en het slachtoffer evenwichtiger worden behandeld. ${ }^{40 r}$

I3I. Op I5 mei 2008 werd een wetsvoorstel ingediend tot instelling van de dualiteit van de strafrechtelijke en de burgerlijke fout in het kader van onopzettelijke slagen en verwondingen en onopzettelijke doding. ${ }^{402}$ In een in te voegen artikel $420 t e r$ Sw. wordt bepaald dat onder het begrip gebrek aan voorzichtigheid of voorzorg de zware fout of de gewoonlijk voorkomende lichte fout wordt verstaan, welke moet worden beoordeeld rekening houdend met de werkelijke mogelijkheden tot waakzaamheid van de beklaagde. Met die bepaling wordt aan het strafrechtelijk foutbegrip een duidelijk beperkende omschrijving gegeven en wordt ook aangegeven dat in concreto moet worden beoordeeld. In een in artikel 4 VT Sv. in te voegen lid wordt bepaald dat de afwezigheid van een strafrechtelijke veroordeling geen beletsel vormt voor het instellen van een vordering voor de civiele rechtbanken, om er met toepassing van de civielrechtelijke regels schadevergoeding te krijgen. De verantwoording van het voorstel bevat naast de argumenten die reeds bij vorige voorstellen werden aangevoerd ook de overweging dat het niet wenselijk is dat lokale mandatarissen voor kleine onachtzaamheden - bijvoorbeeld een gebrekkige verkeersinfrastructuur of signalisatie - strafrechtelijk zouden worden veroordeeld wegens een onopzettelijk letsel-misdrijf.

I32. Het wetsvoorstel werd voorgelegd aan de afdeling wetgeving van de Raad van State, die de volgende bedenkingen had: ${ }^{403}$

- is het criterium van zware fout of de gewoonlijk voorkomende lichte fout wel gerechtvaardigd indien wordt uitgegaan van het criterium van de werkelijke mogelijkheden van de beklaagde? Immers, indien er in het licht van die werkelijke mogelijkheden een laakbaar verzuim is, moet er dan nog wel voor strafbaarheid een ernstig verzuim zijn;

- het criterium van de zware fout of gewoonlijk voorkomende lichte fout is niet nieuw; het komt voor in artikel I8 van wet van 3 juli 1978 betreffende de arbeidsovereenkomsten en in de wet van ro februari 2003 betreffende de aansprakelijkheid van en voor personeelsleden in dienst van openbare rechtspersonen;

- de voorgestelde wijziging heeft alleen betrekking op de onopzettelijk letsel-misdrijven; moet op straffe van schending van het gelijkheidsbeginsel de wijziging ook niet gelden voor andere onachtzaamheidsmisdrijven van het Strafwetboek?;

- de aan artikel 4 VT Sv. voorgestelde wijziging heeft een te breed karakter; het zou op basis van de voorgestelde tekst mogelijk zijn om bij een vrijspraak door de strafrechter voor een opzettelijk misdrijf voor de civiele rechter een schadevergoeding te vorderen; indien de bepaling beperkt is tot de onopzettelijk

40 I Parl. St. Kamer, I997-98, nr. I574/I, 3; Parl. St. Senaat, I999-0o, nr. 2-298/I, p. 2.

402 Parl. St. Kamer, 2007-08, nr. 52-II70/ooI.

403 Parl. St. Kamer, 2007-o8, nr. 52-II70/003 
letsel-misdrijven is niet duidelijk of de civiele rechter elke beslissing van de strafrechter, ook die welke geen verband houdt met de graad van fout, aan de orde kan stellen.

I33. Als gevolg van het advies van de Raad van State werden amendementen ingediend om ook voor andere onachtzaamheidsmisdrijven uit het Strafwetboek te bepalen dat onachtzaamheid bestaat in de zware fout of de gewoonlijk voorkomende lichte fout, te beoordelen volgens de werkelijke mogelijkheden tot waakzaamheid en achtzaamheid van de beklaagde. ${ }^{404}$

\section{Het Franse voorbeeld}

134. De critici van de regel van de eenheid van fout wijzen erop dat Frankrijk, met de wet van Io juli 2000, ${ }^{405}$ is afgestapt van die door de Franse aan de Belgische rechtspraak in I9I2 ontleende regel. ${ }^{406}$

I35. Met de wet van io juli 2000, die als bedoeling had de strafrechtelijke verantwoordelijkheid van verkozenen en ambtenaren te beperken, ${ }^{407}$ werden onder meer artikel I2I-3 Code pénal en artikel 4-I Code de procédure pénale gewijzigd.

136. Na de wijziging van het derde lid en de invoeging van een vierde lid, heeft artikel I2I-3 de volgende inhoud:

'Il n'y a point de crime ou de délit sans intention de le commettre.

Toutefois, lorsque la loi le prévoit, il y a délit en cas de mise en danger délibérée de la personne d'autrui.

Il y également délit, lorsque la loi le prévoit, en cas de faute d'imprudence, de négligence ou de manquement à une obligation de prudence ou de sécurité prévue par la loi ou le règlement, s'il est établi que l'auteur des faits n'a pas accompli les diligences normales compte tenu, le cas échéant de la nature de ses missions ou des ses fonctions, de ses compétences ainsi que du pouvoir et des moyens dont il disposait.

Dans le cas prévu par l'alinéa qui précède, les personnes physiques qui n'ont pas causé directement le dommage, mais qui ont créé ou contribué à créér la situation qui a permis la réalisation du dommage ou qui n'ont pas pris les mesures permettant de l'éviter, sont responsables pénalement s'il est établi qu'elles ont, soit violé de façon manifestement délibérée une obligation particulière de

404 Parl. St. Kamer, 2007-08, nr. 52-II70/004.

405 F. Le Gunehec, 'La loi n ${ }^{\circ}$ 2000-647 du ro juillet 2000 tendant à preciser la définition des délits non intentionnels', JCP 2000, nr. 36, I590.

406 Hennau-Verhaegen, Droit pénal général 2003, p. 354, nr. 4I0; G. Schamps, 'Le relâchement des liens entre responsabilité pénale et civile ..., l.c., 4I8; J. Verhaegen, 'Vers l'abandon d'une jurisprudence séculaire. ... ', l.c., 517.

407 B. Bouloc, Droit pénal général, Parijs: Dalloz 20II, p. 256, nr. 29 I (hierna: Bouloc, Droit pénal général 2011); M. Rassat, Droit pénal spécial. Infractions du Code pénal, Parijs: Dalloz 20II, p. 4I6-4I7, nr. 358 (hierna: Rassat, Droit pénal spécial 2011). 
prudence ou de sécurité prévue par la loi ou le règlement, soit commis une faute caractérisée et qui exposait autrui à une risque d'une particulière gravité qu'elles ne pouvaient ignorer.

Il n'y a point de contravention en cas de force majeure'

137. Uit het gewijzigde artikel I2I-3, derde lid, Code Pénal volgt dat de dader onachtzaam is als hij geen normale voorzichtigheid aan de dag legt, rekening houdend met de aard van zijn opdracht of functie, bevoegdheden, macht en beschikbare middelen. ${ }^{408}$ Die regel wijkt op zich weinig af van de wijze waarop de Belgische rechtspraak het strafrechtelijk foutbegrip in de praktijk beoordeelt en er kan in elk geval uit artikel I2I-3, derde lid, Code Pénal niet worden afgeleid dat de beoordeling van het strafrechtelijk foutbegrip dient te gebeuren rekening houdend met de persoonlijkheidskenmerken van de dader. ${ }^{409}$

I38. Op de algemene regel wordt met het vierde lid een uitzondering geformuleerd:

- indien volgens artikel I2I-3, derde lid, een onachtzaamheid wordt vastgesteld,

- zijn fysieke personen (en dus niet rechtspersonen ${ }^{4{ }^{10}}$ ),

- die niet rechtstreeks de schade hebben veroorzaakt (en die dus verantwoordelijk zijn voor de verder liggende oorzaak),

- maar die de toestand die heeft geleid tot schade, in het leven hebben geroepen of daartoe hebben bijdragen of die geen maatregelen hebben genomen om ze te vermijden,

- slechts strafrechtelijk aansprakelijk,

- als blijkt dat zij ofwel op een manifest weloverwogen wijze een bij wet of reglement bepaalde bijzondere verplichting tot voorzichtigheid of veiligheid hebben geschonden, ofwel een gekarakteriseerde fout hebben begaan die een ander blootstelde aan een risico met een bijzondere ernst dat zij niet konden negeren.

I39. Fouten die niet rechtstreeks ${ }^{4 I I}$ de schade hebben veroorzaakt, zullen slechts strafbaar zijn indien blijkt dat ze voldoen aan de voorwaarden van artikel I2I-3, vierde lid, Code pénal, of met andere woorden als het gaat om zware fouten..$^{412}$

I40. Volgens artikel 4-I Code de procédure pénale belet de afwezigheid van een strafrechtelijke niet-opzettelijke fout in de zin van artikel I2I-3 Code pénal het instellen van een op artikel ${ }_{13} 83$ Code civil gesteunde schadevergoedingsvordering voor de civiele rechter niet, indien het bestaan van een civiele fout in de zin van artikel ${ }_{1} 383$ Code Civil wordt aangetoond. Volgens artikel 470 Code de procédure pénale kan de

408 Zie i.v.m. 'imprudence, de négligence ou de manquement à une obligation de prudence ou de sécurité prévue par la loi ou le règlement': Rassat, Droit pénal spécial 2011, p. 4I8-429 nr. 359-367.

409 Vgl. J. Verhaegen, 'Vers l'abandon d'une jurisprudence séculaire. ... ', l.c., 517.

4IO Bouloc, Droit pénal général 2011, p. 257, nr. 291.

4II Zie over het begrip rechtstreeks veroorzaakt: Rassat, Droit pénal spécial 2011, p. 432-434, nr. 379$37 \mathrm{I}$.

4I2 Bouloc, Droit pénal général 2011, p. 257, nr. $29 \mathrm{I}$. 
strafrechter, ook in geval van vrijspraak, kennis nemen van een schadevordering volgens de regels van het civiele recht. ${ }^{413}$

I4I. Zelfs rekening houdend met het beperkt toepassingsgebied van artikel I2I-3, vierde lid, Code Pénal valt niet te ontkennen dat de Franse wetgever is afgestapt van de regel van de eenheid van fouten. ${ }^{414}$

\section{Beoordeling}

I42. Het komt de wetgever toe te beslissen welke rechtsgoederen strafrechtelijke bescherming behoeven. Er lijkt weinig twijfel over dat het leven en de fysieke integriteit fundamentele waarden zijn die strafrechtelijk moeten worden beschermd. Alleen al de maatschappelijke kost van de aantasting van het leven en de fysieke integriteit verantwoordt het gebruik van het strafrecht, ook als die aantasting slechts het gevolg is van onachtzaamheid. Er lijkt binnen de samenleving geen consensus te bestaan om degelijke aantastingen uit onachtzaamheid niet langer strafrechtelijk te sanctioneren. Dat is zelfs het geval voor de medische sector. ${ }^{415}$

I43. De kritiek van de rechtsleer op de Belgische regeling van de onachtzaamheid als moreel bestanddeel van de onopzettelijk letsel-misdrijven is in zijn essentie terug te brengen tot twee punten:

- de strafrechter moet de onachtzaamheid beoordelen rekening houdend met de persoonlijke eigenschappen van de dader en dus niet via het abstract criterium van de NVR-persoon;

- voor strafbare onachtzaamheid is een zware fout vereist.

Is een dergelijke aanpassing van de regeling mogelijk via jurisprudentiële weg of moet de wetgever ageren?

I44. Het Hof van Cassatie zou zijn rechtspraak kunnen aanpassen en aan het begrip gebrek aan voorzichtigheid en voorzorg van de artikelen 4I8-420 Sw. een striktere inhoud geven en of oordelen dat het foutcriterium moet worden beoordeeld in het licht van de persoonlijke eigenschappen van de dader. Een dergelijke optie lijkt evenwel niet voor de hand liggend:416

- de rechtspraak van het Hof over de eenheid van fouten is stevig gevestigd;

- uit de parlementaire voorbereiding van het Strafwetboek kan moeilijk worden afgeleid dat de wetgever enkel zware fouten wilde bestraffen;

- een andere invulling geven aan het gebrek aan voorzichtigheid en voorzorg lijkt niet alle problemen op te lossen;

4I3 Bouloc, Droit pénal général 2011, p. 258, nr. 293.

4I4 Bouloc, Droit pénal général 2011, p. 257-258, nr. 292-293; Rassat, Droit pénal spécial 2011, p. 445, nr. 379 .

4 I5 G. Schamps, 'La subsidiarité du droit pénal par rapport au droit de la responsabilité civile ...', l.c., I66, nr. 7.2.

4I6 A. Meeus, 'Faute pénale et faute civile', l.c., nr. II.90o/3verso. 
- het behoort niet tot de traditie van de Belgische cassatierechter om in plaats van andere staatsmachten beleidskeuzes te maken.

I45. De nagestreefde wijziging lijkt dan ook een wetgevende tussenkomst te vergen. Wetgevende initiatieven stierven in het verleden echter een stille dood, zodat men zich kan afvragen of een meerderheid van de wetgevende macht zich wel in de voorstellen kan vinden. De in deel 2 geschetste wetsgeschiedenis blijkt op het tegendeel te wijzen. De wetgever heeft niet geaarzeld om de straffen voor de onopzettelijk letsel-misdrijven in de verkeerscontext substantieel te verhogen, ook al is tijdens de besprekingen de regel van de eenheid ter sprake gekomen. Dit heeft de wetgever echter niet kunnen overtuigen. Het verlaten van de lichtste fout als ondergrens voor onachtzaamheid en die optrekken tot een zware fout lijkt in elk geval in een verkeerscontext niet evident.

I46. Zoals reeds aangegeven kent het Belgisch strafrecht naast de onopzettelijk letsel-misdrijven nog misdrijven waar onachtzaamheid de vereiste dan wel een voldoende schuldvorm is. De hierboven weergegeven kritiek heeft op die andere misdrijven geen betrekking. Vereist het gelijkheidsbeginsel niet dat ook voor die misdrijven, die beogen rechtsgoederen te beschermen die minder waardevol lijken dan het leven en de fysieke integriteit, de onachtzaamheid wordt beperkt tot zware fout? Dit lijkt ook te moeten gelden voor de overtredingen en wanbedrijven uit bijzondere strafwetten. Het lijkt moeilijk verdedigbaar dat voor nachtlawaai uit onachtzaamheid of een lozing van afvalwater voor strafbaarheid de lichtste fout zou volstaan, terwijl voor de aantasting van het leven en de fysieke integriteit een zware fout zou worden vereist. Indien onachtzaamheid wordt beperkt tot de zware fout lijkt het aangewezen het begrip duidelijk te omschrijven en de bepaling op te nemen in boek I van het Strafwetboek.

I47. De regel van de eenheid van fouten moet ook worden geschetst tegenover de rol die het slachtoffer in het Belgische strafprocesrecht kan spelen. ${ }^{47}$ Hij kan door zich burgerlijke partij te stellen zijn op een misdrijf gesteunde civiele rechtsvordering bij de strafrechter aanhangig maken en daartoe zelfs de strafvordering op gang brengen. Hij hoeft helemaal niet naar de civiele rechter en hij kan gebruik maken van het door het Openbaar Ministerie verzamelde bewijsmateriaal. Terecht wordt de vraag gesteld of dit het strafproces niet van zijn doel afwendt en of de beoordeling van de civiele rechtsvordering niet volledig aan de civiele rechter moet worden overgelaten, ${ }^{48}$ maar dat is niet de keuze van de Belgische wetgever. In die context valt toch wel iets zeggen voor de stelling dat de regel van de eenheid van fouten het voordeel van de eenvoud heeft. Een rechter beslist op basis van dezelfde criteria over

$4 \mathrm{I} 7$ W. Brosens, 'Het morele bestanddeel der misdrijven en het toekomstige strafwetboek', l.c., I83I. 4I8 R. Dalcq, 'Faute civile et faute pénale ...', l.c., p. 8I. 
zowel de strafvordering als over de civiele rechtsvordering. De partijen hoeven niet meer langs de civiele rechter, ${ }^{419}$ wat in een duaal stelsel wel het geval kan zijn. ${ }^{420}$

I48. Verder is omtrent de kritieken op de regel van de eenheid van fouten en het optrekken van de ondergrens van het foutbegrip nog het volgende op te merken:

- het slachtoffer dat ervoor kiest om zijn civiele rechtsvordering bij de strafrechter aanhangig te maken, weet of moet weten dat ingeval van vrijspraak wegens het niet aangetoond zijn van een fout, hij zich niet meer tot de civiele rechter kan wenden;

- het is evident dat een beoordeling van de strafrechtelijke fout niet mag gebeuren in functie van de belangen van de slachtoffers, maar het is maar de vraag of de suggestie dat de strafrechter zijn oordeel over het voorhanden zijn van onachtzaamheid laat afhangen van de financiële belangen van het slachtoffer, met de werkelijkheid overeenstemt; die suggestie zou evengoed kunnen worden gemaakt voor andere misdrijven dan de onopzettelijk letsel-misdrijven en zelfs omtrent de civiele rechter;

- de voorstellen om de lichtste fout te vervangen door de zware fout geven niet aan hoe die zware fout precies moet worden bepaald en waar precies de lijn ligt tussen een lichte en een zware fout, ${ }^{42 \mathrm{I}}$ ook al is het begrip zware fout in het civiele recht niet onbekend; het lijkt erop dat de discussie van geen of wel fout zal verschuiven naar geen of wel zware fout;

- het onderscheid tussen een abstracte en een concrete beoordeling van het foutbegrip is in de praktijk moeilijk te maken; ${ }^{422}$ de strafrechters blijken niet volstrekt abstract te toetsen, maar houden wel degelijk rekening met het concrete kader, wat overigens ook geldt voor de civiele rechters;

- een beoordeling van het foutbegrip in functie van persoonlijke kenmerken zoals jeugdige leeftijd, slechte gezondheid, gebrekkige kennis of intelligentie lijkt de doelstelling van het vermijden van het door het strafrecht ongewenste gedrag te ondergraven; houdt een dergelijke beoordeling immers niet in dat bijvoorbeeld voor een heel jonge of een heel oude autobestuurder de lat voor strafbare onachtzaamheid hoger ligt dan voor een gemiddelde ervaren bestuurder; ${ }^{423}$

- het valt niet te ontkennen dat onze samenleving complexer is geworden en dat daardoor de kans op het veroorzaken van schade groter is geworden, maar daartegenover staat dat in onze complexe samenleving ook een lichte fout ernstige schade kan veroorzaken; ${ }^{424}$

4I9 Voorontwerp van Strafwetboek, p. I36.

420 W. Brosens, 'Het morele bestanddeel der misdrijven en het toekomstige strafwetboek', RW I97879, I83I.

42I J. D'Haenens, 'L'incrimination non intentionnelle dans le droit pénal codifié et réglementaire', Rev. dr. pén. $1994,464$.

422 Voorontwerp van Strafwetboek, p. 136.

423 W. Brosens, 'Het morele bestanddeel der misdrijven en het toekomstige strafwetboek', l.c., I83o.

424 Voorontwerp van Strafwetboek, p. 136. 
- het verschil in doelstelling tussen het strafrecht en het civiele recht hoeft niet te beletten dat eenzelfde foutbegrip wordt gehanteerd. Het lijkt eerder onlogisch om twee begrippen van onachtzaamheid naast elkaar te laten bestaan; ;25

- het voorstel om in een duaal systeem de strafrechter ook bij een vrijspraak uitspraak te laten doen over de civiele rechtsvordering doet afbreuk aan het principe van het accessoir karakter van de civiele rechtsvordering;

- in zoverre de kritiek betrekking heeft op het absoluut karakter van het gezag van strafrechtelijk gewijsde en op de verjaringsregeling voor de op een misdrijf gesteunde civielrechtelijke vordering is hij door de hierboven geschetste evolutie in de rechtspraak en de wetgeving achterhaald;

- de tendens tot objectivering van de civiele fout doet geen afbreuk aan de regel dat het uitgangspunt voor de civielrechtelijke aansprakelijkheid wel degelijk de fout is ${ }^{426}$ en ook in het verbinden van de vergoedingsplicht aan het creëren van risico en niet langer aan schuld, kan moeilijk een argument worden gezien om de regel van de eenheid van fouten te doorbreken; ${ }^{427}$

- uit de praktijk blijkt dat de strafrechter bij de bestraffing met de graad van fout wel degelijk rekening houdt en dat in geval van lichte fout verzachtende omstandigheden worden aangenomen of hij zich beperkt tot een gewone schuldigverklaring. ${ }^{428}$

I49. De bal lijkt in het kamp van de wetgever te liggen.

425 Verslag commissie herziening strafwetboek, p. 84; W. Brosens, 'Het morele bestanddeel der misdrijven en het toekomstige strafwetboek', RW I978-79, I83I-I832.

426 Verslag commissie herziening strafwetboek, p. 84 .

427 Verslag commissie herziening strafwetboek, p. 84 .

428 Voorontwerp van Strafwetboek, p. 136; W. Brosens, 'Het morele bestanddeel der misdrijven en het toekomstige strafwetboek', l.c., I830 en I832. 